\title{
Will It Be Possible to Put into Practice the Mitigation of Ventilation Air Methane Emissions? Review on the State-of-the-Art and Emerging Materials and Technologies
}

\author{
Anna Pawlaczyk-Kurek * and Mikołaj Suwak (D) \\ Institute of Chemical Engineering, Polish Academy of Sciences, ul. Baltycka 5, 44-100 Gliwice, Poland; \\ mikolaj.suwak@iich.gliwice.pl \\ * Correspondence: ania.pawlaczyk@iich.gliwice.pl
}

Citation: Pawlaczyk-Kurek, A.; Suwak, M. Will It Be Possible to Put into Practice the Mitigation of Ventilation Air Methane Emissions? Review on the State-of-the-Art and Emerging Materials and Technologies. Catalysts 2021, 11, 1141. https:// doi.org/10.3390/catal11101141

Academic Editor: Eleni Iliopoulou

Received: 23 July 2021

Accepted: 17 September 2021

Published: 23 September 2021

Publisher's Note: MDPI stays neutral with regard to jurisdictional claims in published maps and institutional affiliations.

Copyright: (c) 2021 by the authors. Licensee MDPI, Basel, Switzerland. This article is an open access article distributed under the terms and conditions of the Creative Commons Attribution (CC BY) license (https:// creativecommons.org/licenses/by/ $4.0 /)$.

\begin{abstract}
The work refers to the important problem of methane emissions in relation to the ventilation air methane (VAM) emitted to the atmosphere. VAM is fuel that remains unused in most mines around the world due to the low content of the combustible component in the mixture $(0.1-1 \%)$. The aim of this article is to present the real problems posed by released VAM in its utilization such as variability of flow, methane concentration, or possible presence of gaseous and non-gaseous pollutants. The paper presents the existing technologies that are ready to be implemented or have a reliable potential to be implemented in the industry and those whose development will have strong influence on the effective reduction in VAM emissions. The methods discussed include enrichment, thermal, and catalytic as well as photocatalytic oxidation. The catalysts dedicated to VAM oxidation were reviewed. The literature studies show that currently developed technologies enable more and more efficient oxidation of VAM. The most technologically advanced implemented solutions are based on the thermal oxidation method in TFRR. Catalytic methods are still at the laboratory research phase, but have been intensively developed and have the potential to be implemented at process scale in the future.
\end{abstract}

Keywords: catalytic methane combustion; ventilation air methane; methane utilization; catalyst; reactor

\section{Introduction}

One of the major problems associated with coal mining is the presence of adsorbed methane from hard coal seams that is released during the mining process [1]. Methane as an explosive gas poses a fatal threat to working miners when its concentration in the air is in the range of 5-15\% [2]. In order to maintain safe working conditions underground, it is essential to ensure a constant air flow. Mine ventilation systems keep the methane concentration below the lower explosive limit. The average methane content in the ventilating air can vary significantly depending on the coal mine location. In Poland, the value of the methane content in the ventilation air is rather low, usually $0.3 \%$ (it can be higher but never exceeds $0.75 \%$ ), but in Australia, it can reach the value of more 1 [3], in the USA, it may even slightly exceed 1\% [4], and in India, the concentration of methane ranges from 0.2 to $0.4 \mathrm{vol} . \%$ [5]. Despite the low concentration of methane, the mine ventilation air flow rate is high enough to emit significant amounts of methane to the atmosphere. For this reason, ventilation air methane (VAM) is an important source of anthropogenic methane emission [6]. The global emission of VAM is increasing and, according to the literature, this trend will continue in the future. The MC2M calculation model [7] predicts a 2.5-fold increase in VAM emissions over a 40-year time frame to achieve a value of $318 \mathrm{bcm}$ in 2050 .

The need to minimize methane emissions is strictly related to its high global warming potential (GWP) of 37 over a 100-year time horizon [8]. This means that methane absorbs 37 times more heat than the equivalent mass of carbon dioxide, and therefore 
contributes much more to the greenhouse effect. Methane emissions account for $16 \%$ of global greenhouse gas emissions (see Figure 1).

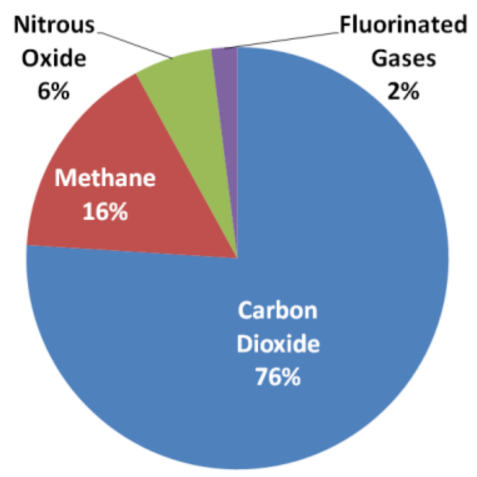

(a)

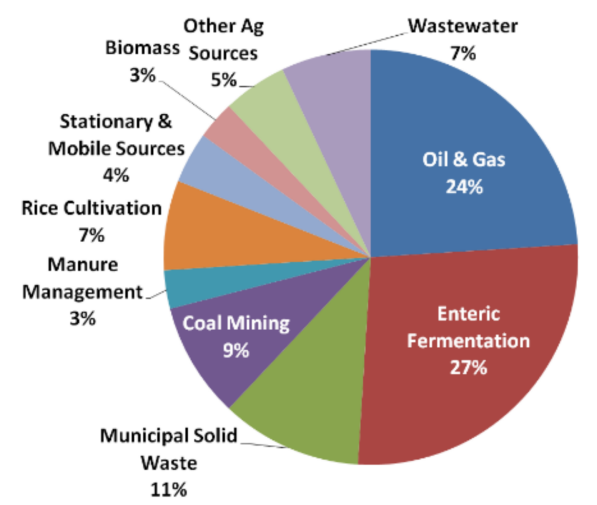

(b)

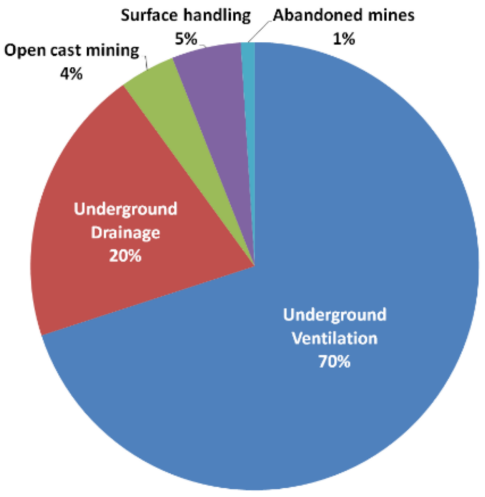

(c)

Figure 1. (a) Global greenhouse gas emissions by gas [9]. (b) Global methane emissions by sector [10]. (c) Methane emissions from coal mining by source.

It is estimated that about $50 \%$ of this amount comes from anthropogenic sources. It is recognized that the locally increased emissions of this gas may lead to local temperature increases, which results in the occurrence of abnormal meteorological phenomena. The methane emission standards have become more and more restrictive, which forces coal mining companies to take actions to reduce the VAM emissions to the atmosphere. The world mining industry does not use the full energy potential of VAM. This fact results basically from two things: a relatively low fee for the so-called use of the environment, but also the conditions under which a VAM disposal plant would have to operate. In the near future, changes in the EU legislation related to the inclusion of methane in the ETS fee system can be expected. The change will relate to the method used for the calculation fee for the emission of a ton of methane, which will be determined based on the greenhouse potential of this gas. As a result, the countries to which this fee will apply will be burdened with huge costs. It is advantageous that the new ETS fee system will force the mining industry to take decisive steps toward reducing VAM emissions using the existing technological solutions or developing new ones. In the future, an increase in gas emission standards should be expected. It will mean that other countries (such as Russia, Ukraine) related to the mining industry will also be obliged to reduce VAM emissions. It is predicted that India will probably also join these countries due to the desire to achieve coal self-sufficiency by significantly increasing the amount of coal mined (up to one billion tons), which will also increase VAM emissions. China, as the largest emitter of VAM [11], together with the Australia and the USA release $82 \%, 66 \%$, and $52 \%$ of the total amount of methane emitted from hard coal beds, respectively. These countries are also the biggest VAM emitters in the world [12] and are investing significant resources in the development of technology to reduce the emissions.

The technologies that have been implemented so far on an industrial scale are based on the reduction in VAM emissions mainly by thermal combustion. Others based on catalytic processes are being intensely developed. There is a growing interest in technologies enabling the enrichment of the methane-air mixture to such concentrations of methane that will enable its use in the already existing devices that require higher contents of the combustible component in the feed mixture for proper operation.

This work is a brief overview of the VAM abatement technologies that have been implemented or are still being developed and studied. Moreover, the difficulty of the practical use of VAM was considered based on a detailed literature analysis. The greatest challenge for modern science in terms of reducing VAM emissions is developing a method 
for the utilization of mine ventilation air with a low concentration of methane (below $0.4 \%$ ) and a ultra-low amount (below $0.2 \%$ ). In order to solve this problem, the use of catalytic combustion reactors was proposed. It can be seen that the potential use of catalytic reactors for the combustion of VAM is gaining more and more interest among the scientists over the last 20 years (Figure 2).

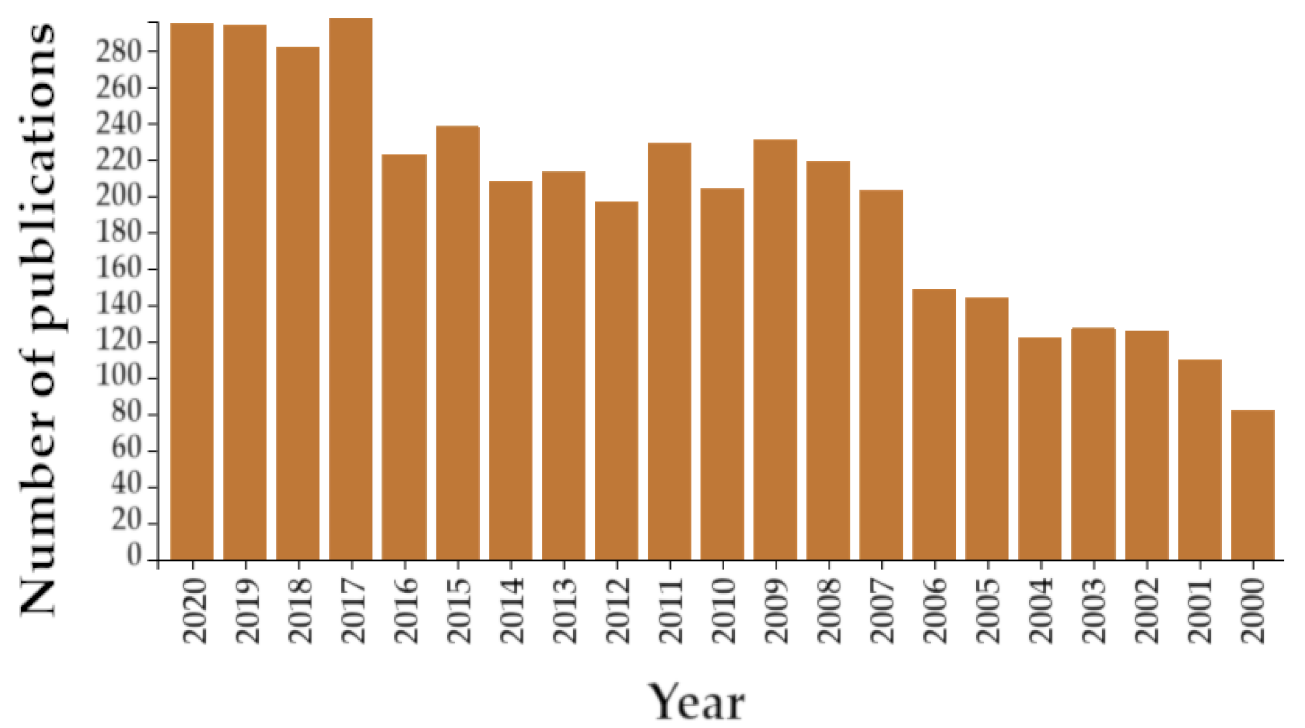

Figure 2. Number of publications per year based on www.webofscience.com (accessed on 21 June 2021) results analysis for the topics "catalytic methane combustion" or "catalytic methane oxidation" and "ventilation air methane" taken 21 June 2021.

The article collects data of catalysts that are dedicated and are proposed for catalytic reaction oxidation of methane in conditions of its very high dilutions in the air. The issue of the realistic applicability of the proposed catalysts for VAM combustion in industrial conditions will be discussed.

\section{Characteristics of the VAM}

The gas released from coal seams is a big problem for mining operations. The methane, which is stored in a micro-porous network of coal seams, was formed during a coalification process $[13,14]$. The higher ranked the coal, the more methane it contains [7]. Properly adapted ventilation is intended to reduce the concentration of methane per volume unit to a level that guarantees the safety of workers.

VAM is such a mixture of methane and air, where methane concentration is very lean, usually below 1 vol. \%. The amount of methane released per one ton will be different at different mine locations. For example, in Poland, the amount of VAM emitted into the atmosphere per ton of extracted coal mined is over $9 \mathrm{~m}^{3}$, in Indian gassy mines, the value is more than $10 \mathrm{~m}^{3}$ [5]. It would be supposed that reducing the number of mines will solve the problem of VAM emissions, or at least reduce it. The problem of methane emission is still present even after decades of coal mine abandonment [7]. Furthermore, it turned out that even a significant reduction in coal extraction and the number of mines does not lead to a reduction in VAM, which has been noticed in Poland. As reported in [9], there are several factors contributing to this phenomenon such as increasing longwall lengths, mining speed, and increasing the saturation of coal seam related to deeper exploitation of the raw material (e.g., in some Polish coal mines, coal is extracted from $1000 \mathrm{~m}$ below the ground level [15]).

Characteristics of VAM include dust load, particle size, mineral matter of the dust, variation in methane concentration and flow rate, possibility of the existence of other gaseous pollutants such as $\mathrm{H}_{2} \mathrm{~S}$ or $\mathrm{SO}_{2}[3,16], \mathrm{He}, \mathrm{H}_{2}, \mathrm{HCN}, \mathrm{NH}_{3}, \mathrm{NO}_{\mathrm{x}}, \mathrm{H}_{2} \mathrm{~S}, \mathrm{SO}_{2}$ [17], 
and high amount of water [18]. The fresh air composition supplied to the mine undergoes unfavorable changes, which are the result of mixing gases flowing out of rocks and gases resulting from technological processes and oxidation processes with the pumped air. The temperature of the air rises when it comes into contact with the rock mass and with power devices, and the humidity is also increased. It is worth mentioning that the availability of detailed data of the VAM characteristics is poor and insufficient. The indicated parameters characterizing ventilation air cannot be generalized on the scale of the mining region or the country. Detailed data are important for selecting the appropriate technology for VAM disposal. A good example is an article by [3], which summarizes the results of the three-month tests of the measurement results of compositions of ventilation air emitted to the atmosphere from four gaseous Australian mines. It was shown that the measured values were different between the examined objects, but also depended on the currently conducted mining works (see Table 1).

Table 1. The chosen data of VAM at different coal mines.

\begin{tabular}{|c|c|c|c|c|c|}
\hline \multirow{2}{*}{ Parameter $^{1}$} & \multicolumn{4}{|c|}{ Australia } & \multirow{2}{*}{$\begin{array}{c}\text { Turky } \\
\text { Kozlu } \\
\text { Mine-Turky [14] }\end{array}$} \\
\hline & $\begin{array}{c}\text { Mine A } \\
{[3]}\end{array}$ & $\begin{array}{c}\text { Mine B } \\
{[3]}\end{array}$ & $\begin{array}{c}\text { Mine C } \\
{[3]}\end{array}$ & $\underset{[3]}{\text { Mine D }}$ & \\
\hline Flow rate $\left[\mathrm{m}^{3} / \mathrm{s}\right]$ & $230-260$ & 120-195 & $370-390$ & $200-230$ & $85-97$ \\
\hline Relative humidity [\%] & 100 & $85-100$ & $74.5-83.5$ & $73-99.8$ & No data \\
\hline Dust loading $\left[\mathrm{mg} / \mathrm{m}^{3}\right]$ & $0.13-4.47$ & $0.25-3.87$ & $0.67-3.82$ & $0.21-3.19$ & No data \\
\hline Methane conc. [vol.\%] & $0.08-0.92$ & $0.16-1.4$ & $0.04-0.19$ & $0.32-1.68$ & $0.6-0.9$ \\
\hline
\end{tabular}

${ }_{1}^{1}$ Other gases such as $\mathrm{CO}, \mathrm{H}_{2} \mathrm{~S}$, and $\mathrm{SO}_{2}$ were not detected.

As reported by other sources, the VAM flow rate can achieve even $600 \mathrm{~m}^{3} / \mathrm{s}[19,20]$ and daily dust loading can reach $232 \mathrm{~kg}$ [21]. It should be considered that all mentioned parameters generate huge technical problems in the implementation of any known and available technology or currently being developed technology to an industrial scale. The first of those is the flow rate, the scale of which does not enable the process to be limited to only one apparatus. Moreover, the nearly completely steam-saturated stream leaving the ventilation shaft will pose problems in any industrial process. In the case of catalysts, the humidity will inhibit oxidation [22-24] by covering active places on the catalyst bed. In other cases, when the ambient temperature is lower than the temperature of VAM from the ventilation shaft, excess moisture will condense out in pipes and other apparatus. The risk caused by a large amount of dust may increase the flow resistance in devices filled with a fixed bed or decrease the efficiency of the catalyst by clogging key areas on the surface. A major problem in the utilization of VAM is the content of methane. An even greater problem is the possibility of its variability and significant difference between the maximum and minimum value from the one measuring point. In the case of very large differences obtained on one ventilation shaft, the selection of the method of utilization of such a mixture becomes difficult.

\section{A Contemporary Approach to VAM Utilization}

Intensive interest in the problem of methane utilization from mine ventilation air appeared in the last decade of the twentieth century. It was due to the establishment of the Intergovernmental Panel on Climate Change (IPCC) in 1988 and the requirements of the Kyoto Protocol signed in 1997 [25]. Moreover, it was realized that due to very high flow rates of ventilation air, low methane concentration in VAM causes high methane emissions to the atmosphere. According to [2], global methane emissions in this way amount to 16 billion $\mathrm{m}^{3}$ per year. This amount is close to the annual consumption of natural gas in Poland since domestic consumption in 2018 reached 17.2 billion $\mathrm{m}^{3}$ (excluding exports).

A good classification of the ways of using this fuel can be found in the review by [26]. Only the underlined technologies in Figure 3 were considered in this article. 


\section{Combustion technologies of VAM}

\begin{tabular}{|l|l|l|}
\hline \multicolumn{1}{|c|}{ Ancilary Uses } & \multicolumn{1}{c|}{ Principal Uses } \\
\hline \multicolumn{1}{|c|}{ Thermal } & \multicolumn{1}{c|}{ Catalytic } \\
\hline $\begin{array}{l}\text { - Combustion air for gas turbine } \\
\text { - Combustion air for gas engine } \\
\text { - Combustion air for conventional Pf } \\
\text { power station } \\
\text { - Hybrid waste coal/tailing/methane } \\
\text { combustion in fluidized bed } \\
\text { - Hybrid waste coal/tailing/methane } \\
\text { combustion in a kiln }\end{array}$ & $\begin{array}{l}\text { - Catalytic flow reverse } \\
\text { reactor (CFRR) } \\
\text { - Catalytic monolith reactor } \\
\text { (CMR) } \\
\text { - Catalytic lean burn gas } \\
\text { turbine }\end{array}$ & $\begin{array}{l}\text { - Thermal flow reverse } \\
\text { reactor (TFRR) } \\
\text { - Recuperative gas } \\
\text { turbine }\end{array}$ \\
\hline
\end{tabular}

Figure 3. Scheme of combustion technologies of VAM.

The analyzed methods were divided into two basic categories:

(A) Ancillary use, where VAM is added (auxiliary) to power equipment where the high combustion temperature is provided by another base fuel.

(B) Principal use, where VAM is the primary or even sole fuel.

Category (A) includes those solutions in which the ventilation air would replace the atmospheric air introduced in known combustion methods [27]. Thus, [26] mentioned gas turbines, internal combustion engines as well as (basically primarily) coal-burning power plants and heating devices. It seems that such solutions would be the simplest and cheapest in terms of investment and operation. However, it quickly turned out that these ideas were more theoretical than practical. The ventilation shaft emits several hundreds of thousands of $\mathrm{m}^{3} / \mathrm{h}$ of ventilation air. In Poland, there are shafts operating at flows significantly exceeding one million $\mathrm{m}^{3} / \mathrm{h}$. In order to use such large streams, large power plants of at least several hundred MW would have to be located a short distance from the mine (maximum distance up $6 \mathrm{~km}$ [28]). This condition is difficult to meet, although the supply of local heat plants with at least a part of the ventilation air should be taken into account.

Category (B), in which VAM is the basic fuel, mainly includes the so-called flow reverse reactors, although [26] also mentioned recuperative gas turbines, catalytic combustion turbines, and monolithic recuperative reactors (CMR). A more recent publication [29] showed that solutions using turbine combustion, to be effective, may require upgrading VAM to higher concentrations. Currently, in the literature on VAM utilization, the most attention has been given to reverse reactors, search for new catalysts, and enrichment of VAM, which will be discussed further in more detail.

\subsection{Enrichment Methods}

Growing interesting in the methane enrichment method in VAM has been observed. The goal of the method is to obtain such a level of methane concentration in VAM, which allows for its use as a principal fuel in other applications. Literature data indicate that available lean burn combustion technologies such as carbureted gas turbine (CGT) can operate for methane concentration 0.8 to 1.6 vol.\% [30], similarly catalytic combustion gas turbine [31]. On the other hand, power system generation needs as much as $6 \%$ methane in mixture [32] and power generation with internal combustion needs even more than $10 \%$ $\mathrm{CH}_{4}$ [33]. The problem of the separation of nitrogen and methane is caused by the similarity of chemical and physical properties of those two gases. Various kinds of experiments have been conducted to increase the concentration of methane in mixture with air. Among them, one can find enrichment experiments using the free diffusion of gases in a mechanical 
tower [10], selective membrane methods [34], cryogenic separation, and gas uptake of ionic clathrate hydrates [35].

It was found that methods that rely on adsorption with solid sorbents are promising in the enrichment of lean methane-air mixtures [21,32,36-38]. The various adsorption beds were tested: activated carbon (AC) [39,40], MOF [38], honeycomb monolithic carbon fiber composites [37], zeolitic imidazolate frameworks (ZIFs) [41], carbon composites derived from macadamia nut shell (MNSs), carbon nanotubes (CNTs) [21], carbon molecular sieve (CMS) [42,43], Ba exchanged titanium silicate (Ba-ETS-4) [44], etc.

It is worth mentioning that the lower the methane concentration, the more expensive the enrichment process [39]. This method is profitable when obtained energy combustion of the enrichment mixture is higher than the energy consumed for the regeneration of the sorbent bed. The efficiency of adsorption technology depends on sorbent capacity, the method of removed adsorbed gas [37], and resistance to pollutants such as dust or the presence of other gases in the mixture subjected to the enrichment process [21]. The adsorption on adsorbents needs a cyclic (swing adsorption) regenerative process of the bed. This can be realized by various methods by changing temperature (TSA), pressure (PSA), vacuum (VSA), or the use of a combination of these parameters together (TVSA, TVPSA, VPSA). Due to the huge flow rate of VAM from the shaft, implementing the processes that require pressure would be very expensive. As noted in [37], the operating pressure for the enrichment process should be close to the atmospheric. Table 2 presents the chosen data for adsorption with solid sorbents dedicated to VAM enrichment.

Table 2. The chosen data for adsorption with solid sorbents for VAM enrichment.

\begin{tabular}{|c|c|c|c|c|c|c|c|}
\hline \multirow[t]{2}{*}{ Kind of SA } & \multirow[t]{2}{*}{ Ref. } & \multirow[t]{2}{*}{$\begin{array}{l}\text { Kind of } \\
\text { Adsorbent }\end{array}$} & \multirow[t]{2}{*}{$\begin{array}{l}\text { BET } \\
{\left[\mathrm{m}^{2} / \mathrm{g}\right]}\end{array}$} & \multicolumn{2}{|c|}{$\begin{array}{c}\text { Gas Concentration } \\
\text { [vol.\%] }\end{array}$} & \multirow[t]{2}{*}{$\begin{array}{l}\text { Scale of } \\
\text { Installation }\end{array}$} & \multirow[t]{2}{*}{ Process } \\
\hline & & & & Feed & Result & & \\
\hline PSA & [36] & $\begin{array}{l}\text { Coconut shell } \\
\text { activated carbon }\end{array}$ & 1085 & 0.3 & 1 & $\begin{array}{l}\varphi 20 \times 1500 \mathrm{~mm} \\
\text { Bed: } 0.16 \mathrm{~kg}\end{array}$ & Laboratory \\
\hline VSA & [39] & $\begin{array}{l}\text { Commercial } \\
\text { activated carbon }\end{array}$ & 700 & $\begin{array}{c}4.7 \\
8.05 \\
11.7 \\
17\end{array}$ & $\begin{array}{l}14.3 \\
21.8 \\
29.3 \\
42.2\end{array}$ & $\varphi 20 \times 900 \mathrm{~mm}$ & Laboratory \\
\hline TVSA & [37] & $\begin{array}{l}\text { Honeycomb } \\
\text { monolithic carbon } \\
\text { fiber composite }\end{array}$ & $458-577$ & $\begin{array}{l}0.27 \\
0.32 \\
0.53 \\
0.93\end{array}$ & $\begin{array}{c}2.5 \\
5 \\
7 \\
12\end{array}$ & $30 \times 100 \times 200 \mathrm{~mm}$ & $\begin{array}{l}\text { Laboratory } \\
20 \mathrm{~L} / \mathrm{min}\end{array}$ \\
\hline \multirow[t]{4}{*}{ VPSA } & [30] & $\begin{array}{l}\text { Coconut shell } \\
\text { activated carbon }\end{array}$ & 1155 & 0.2 & 1.2 & $\begin{array}{c}\text { Two columns: } \\
\varphi 1000 \times 1840 \mathrm{~mm} \\
\varphi 550 \times 1440 \mathrm{~mm}\end{array}$ & $\begin{array}{c}\text { Pilot plant } \\
\text { Real VAM + coal mine } \\
\text { methane } 8300 \mathrm{~L} / \mathrm{min}\end{array}$ \\
\hline & [40] & Activated carbon & 1124.3 & $\begin{array}{l}0.1 \\
0.3 \\
0.5 \\
0.7\end{array}$ & $\begin{array}{c}0.21 \\
0.59 \\
0.89 \\
1.2\end{array}$ & $\varphi 60 \times 500 \mathrm{~mm}$ & $\begin{array}{c}\text { Simulation and } \\
\text { experimental (with } \\
\text { similar increase ratio) }\end{array}$ \\
\hline & [32] & Activated carbon & 1077.49 & 1 & 53.5 & $\varphi 27 \times 617 \mathrm{~mm}$ & $\begin{array}{l}\text { Laboratory; displacement } \\
\text { of } \mathrm{CH}_{4} \text { by use } \mathrm{CO}_{2}\end{array}$ \\
\hline & [45] & $\begin{array}{l}\text { Coconut shell } \\
\text { activated carbon }\end{array}$ & 329 & 0.42 & 1.09 & $\varphi 17 \times 500 \mathrm{~mm}$ & $\begin{array}{l}\text { Laboratory } \\
0.65 \mathrm{~L} / \mathrm{min}\end{array}$ \\
\hline \multirow[t]{2}{*}{ VTVSA } & [46] & \multirow{2}{*}{$\begin{array}{l}\text { Honeycomb } \\
\text { monolithic carbon } \\
\text { fiber composite }\end{array}$} & 604 & $\begin{array}{c}0.3 \\
0.6 \\
0.98\end{array}$ & $\begin{array}{l}19.28 \\
24.24 \\
36.92\end{array}$ & \multirow{2}{*}{$\begin{array}{l}\text { Two columns: } \\
134 \times 184 \times 2000 \mathrm{~mm} \\
123 \times 168 \times 1000 \mathrm{~mm} \\
\text { Bed: } 9.97 \mathrm{~kg}\end{array}$} & $\begin{array}{l}\text { Simulation } \\
30 \mathrm{~L} / \mathrm{min}\end{array}$ \\
\hline & [19] & & & $\begin{array}{l}0.58 \\
0.73\end{array}$ & $\begin{array}{l}28.37 \\
32.04\end{array}$ & & $\begin{array}{l}\text { Prototype } \\
\text { Real VAM } \\
22-60 \mathrm{~L} / \mathrm{min}\end{array}$ \\
\hline
\end{tabular}

Among the data given in Table 2, the best results were shown in [32], where methane concentration in the product reached a value of $53.5 \%$ from the mixture containing only $1 \%$ methane. The results were obtained by using pure $\mathrm{CO}_{2}$ displacement due to its stronger adsorption than methane. From the practice point of view, the displacement method would need a huge amount of $\mathrm{CO}_{2}$, which is not feasible for two reasons: lack of a source 
of $\mathrm{CO}_{2}$ close to the ventilation shaft and the high cost of removing the adsorbed $\mathrm{CO}_{2}$ from the sorbent [46]. In the literature, most installations of swing adsorption of VAM stayed on a laboratory scale, where experiments were done with pure gases, without water vapor in a feed stream. Moreover, most of them were applied to enrichment methane-air mixtures where the concentration of the combustible component was for sufficient for use in another technology effectively, for example, in reversal flow reactors. Meanwhile, ultra-low concentration VAM is a challenge for future technologies. The most advanced solution was presented in [30], which worked with real VAM and in which the VPSA method was able to increase the methane level from 0.2 to 1.2 in quite a large scale.

\subsection{Oxidation Methods}

Oxidation is one of the most advanced industrial application methods for VAM utilization as a basic fuel. It is known that the combustion of VAM via conventional processes with some supplementary fuel is indispensable, but modern technology, in restricted ranges of concentration, is able to oxidize the dilute mixture. Currently, in the literature, most attention has been paid to reverse reactors or preheated catalytic reactors so such a solution is discussed in more detail below.

\subsubsection{Implemented Technology}

Due to low $\mathrm{CH}_{4}$ concentration, the most reasonable solution seems to be autothermal combustion in flow-reversal reactors (FRR), which have been intensively developed and studied $[47,48]$. There are two known types of these reactors: the catalytic flow reversal reactor (CFRR) and thermal flow-reversal reactor (TFRR), and both have similar structures. Both are adiabatic fixed bed reactors. The main difference is that in CFRR, except for the inert material, layers of the catalyst are applied. The reactors for exothermic reactions such as methane combustion work autothermally. This reaction, regardless of whether it takes place with or without the use of a catalyst, requires heating to a temperature that allows it to initiate its course. To start-up the reactor, the bed has to be preheated to the appropriate combustion temperature. Afterward, the combustible gas mixture cold feed flowing through the bed is regeneratively heated up by the bed and then combusted. Combustion generates heat and the high-temperature zone moves slowly downstream. It is a cause of the temperature increase inside the reactor and the formation of the so-called heat wave. When the wave is approaching the reactor outlet, to avoid extinction, the flow direction of gas is changed and the process is repeated in the reverse direction. When the amount of heat generated is high, then some part of the heat can be recovered from the center of the reactor and applied for other uses [49,50]. This issue is further described in [4]. Examples of both types of FRRs are depicted in Figure 4.

According to the available data, the minimum concentration of methane in VAM for the FRR is determined: 0.19 [51], $0.2 \%$ [52,53], $0.22 \%$ [54,55], 0.25\% [33,56], 0.3\% [57,58] in case of TFRR, and $0.1 \%$ [59], $0.19 \%$ [60], $0.13 \%$ [61], for catalytic version of reversal reactor. It should be emphasized that despite many years of work, only TFRR reactors have been implemented on an industrial scale for VAM utilization. Examples of implemented installations are presented in Table 3.

The most advanced commercial VAM abatement project is the MEGTEC from the USA, which offers large industrial installations (called the VOCSIDIZER ${ }^{\mathrm{TM}}$ ) with a capacity of over $200,000 \mathrm{~m}^{3} / \mathrm{h}$. The installation located in Australia generates $6 \mathrm{MW}$ of electrical power. Another located in China produces hot water for nearby settlements. 
TFRR

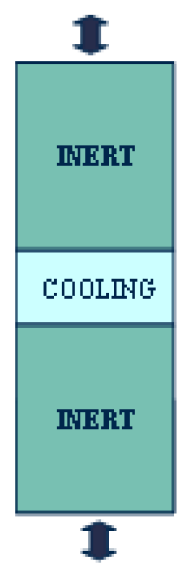

(a)

\section{CFRR}

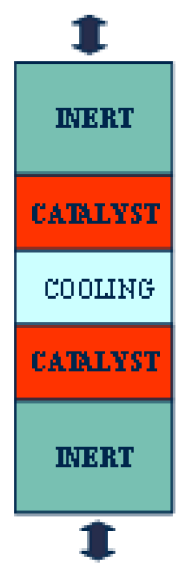

(b)

Figure 4. Scheme of two types of the FRR: (a) TFRR; (b) CFRR.

Table 3. The biggest VAM abatement projects are based on regenerative thermal oxidation technology.

\begin{tabular}{|c|c|c|c|c|c|}
\hline Ref. & Company & Location & $\begin{array}{c}\mathrm{CH}_{4} \text { Conc. } \\
\text { [vol.\%] }\end{array}$ & $\begin{array}{c}\text { Flow Rate } \\
{\left[\mathrm{m}^{3} / \mathrm{h}\right]}\end{array}$ & Number of Units \\
\hline$[62]$ & MEGTEC & $\begin{array}{l}\text { West Cliff Colliery in New South } \\
\text { Wales in Australia }\end{array}$ & $0.9-1$ & 250,000 & 4 \\
\hline [49] & Dürr System & $\begin{array}{c}\text { Marshal County Mine, } \\
\text { West Virginia, USA }\end{array}$ & 1.2 & 270,000 & 3 \\
\hline$[49,63]$ & Dürr System & $\begin{array}{l}\text { Gaohe Mine of the LuAn Mining } \\
\text { Group in Shanxi Province in China }\end{array}$ & 1.2 & $1,080,000$ & 12 \\
\hline [64] & MEGTEC & $\begin{array}{c}\text { Da Tong Mine, } \\
\text { ChonQing Province in China }\end{array}$ & 0.5 & 375,000 & 6 \\
\hline [33] & $\begin{array}{c}\text { MEGTEC } \\
\text { SHENGDONG Cor. }\end{array}$ & $\begin{array}{l}\text { Dafosi Coal Mine, Binchang } \\
\text { Shanxi Province in China }\end{array}$ & $0.9-1.1$ & 300,000 & 5 \\
\hline [65] & Biothermica, JWR & $\begin{array}{l}\text { JWR No. } 7 \text { w Brookwood, } \\
\text { Alabama in USA }\end{array}$ & 0.9 & 51,000 & 1 \\
\hline
\end{tabular}

The VAM utilization project in Gaohe Mine is the largest project in the world. A quite high value of methane in the feed stream (1.2 vol.\%) was achieved by mixing VAM ( 0.31 vol.\%) with low concentration coal mine methane CMM (7.45 vol.\%) [63]. The recovered heat is transferred to the steam boiler. There is a similar situation is another Chinese coal mine, namely the Dafosi Coal Mine, where a higher methane-air mixture is obtained by mixing drained low concentration methane (less than 8\%) with VAM [33]. A different approach to thermal combustion of VAM was proposed in [54]. Instead of combining a few units of TFRR, the authors proposed one reactor with five inserts beds. Additionally, this multibed reactor is fed by a mixture of 1.02 vol.\% of methane prepared from two streams: VAM $(0.3 \%)$ and CMM $(10 \%)$. However, the solutions above-mentioned are able to work with lower methane concentration, but are created in places where not only is VAM emitted to the atmosphere, but also unusable CMM due to not enough methane concentration for another application. According to [33], many coal mines in China are facing a similar problem.

It is considered that high-temperature technology is dangerous due to temperatures up to $1000{ }^{\circ} \mathrm{C}$. While the risk of explosion by positioning methane utilization devices on the surface and thermal insulation is practically impossible, the environmental conditions of the process in the reactor may increase such risk, especially if the mixture to be oxidized is prepared and the methane content is higher than 1\%. The authors in [66] studied the explosion and combustion parameters of mixtures of methane and air with saturated water 
vapor. The tests were carried out at room temperature and atmospheric pressure. It has been shown that water vapor has little impact on all the parameters when methane concentration is lower than $10 \%$. The flammability limits of methane in the humid mixture are narrower $(6-14 \%)$ than in dry methane-air mixtures (5-15\%). The other test was presented in [67]. They tested the risk of explosion of the mixtures with a content of methane $1-1.5 \%$ in temperature of $1000{ }^{\circ} \mathrm{C}$, over ceramic fillings such as monolith honeycombs that are used in many high temperature solutions. The results demonstrated that the tested mixtures are oxidized rather than exploding. The safe oxidation of lean methane-air mixtures for a concentration of about $1 \%$ provides the premise that reactors can operate in such conditions, which contribute to waste heat production for other uses. Additionally, during the experiments described in [55], no sudden pressure surges were observed, which could indicate an explosion.

In most cases around the world, mines do not have additional, untapped methane. In many cases, even if all captured methane had been used for the concentration of VAM, additional supplementation would have been insufficient due to the huge amounts of VAM. Thus, the greatest challenge for modern science in the field of VAM utilization is developing a method of direct utilization of the mixtures where the methane concentration is lower than $0.4 \%$. It should be noted that for methane concentrations below $0.2 \%$, the currently available technologies are not able to operate [68]. It seems that the best solution in this case is oxidation of this mixture in a catalytic reactor. The use of catalysts has many advantages such as a significantly lower ignition point than in the case of thermal combustion, no need to use materials resistant to high temperatures due to the lower operating temperatures of the reactor, and the possibility of oxidizing mixtures with a low content of a combustible component with good conversion. A significant difference in the CFRR and TFRR process parameters is that the reaction starts at lower temperatures in the presence of a catalyst than without it (in case of thermal ignition). Depending on the catalyst used, the difference is about $300{ }^{\circ} \mathrm{C}$.

\subsubsection{Development of Catalytic Technologies}

There are many articles devoted to the catalytic combustion of methane. Only some of them have been dedicated to the oxidation of VAM. This means that the prepared mixture for the experiment consists of methane and air where the methane concentration is $\leq 1 \mathrm{vol} . \%$. Table 4 presents the data of the catalysts tested in the direction of application for VAM combustion.

Table 4. The chosen catalysts proposed for the combustion of lean methane-air mixture such as VAM.

\begin{tabular}{|c|c|c|c|c|c|c|c|}
\hline \multirow{2}{*}{ Ref. } & \multirow{2}{*}{ Catalyst } & \multicolumn{2}{|c|}{ Range of } & \multirow{2}{*}{$\begin{array}{l}\mathrm{T}_{\mathrm{ign}} \\
{\left[{ }^{\circ} \mathrm{C}\right]}\end{array}$} & \multirow{2}{*}{$\begin{array}{c}\mathrm{T}_{\mathbf{x}} \\
{\left[{ }^{\circ} \mathrm{C}\right]} \\
\mathrm{x}-\text { Conversion }[\%]\end{array}$} & \multirow{2}{*}{ Reactor } & \multirow{2}{*}{ Experimental Conditions } \\
\hline & & Temp. $\left[{ }^{\circ} \mathrm{C}\right]$ & $\mathrm{CH}_{4}[\mathrm{vol.} \%]$ in Air & & & & \\
\hline [69] & $\mathrm{Pd} 0.7 \mathrm{~g} / \mathrm{L}$ & $530-560$ & $0.8-1.2$ & 350 & No data & PCRR & $\begin{array}{c}1000 \mathrm{Nm}^{3} / \mathrm{h} \\
\mathrm{SV}=2600-11,5001 / \mathrm{h} ; \mathrm{MB}\end{array}$ \\
\hline [70] & $\mathrm{Pd} 0.7 \mathrm{~g} / \mathrm{L}$ & $420-540$ & $0.6-0.8$ & $\begin{array}{l}\text { No } \\
\text { data }\end{array}$ & $\mathrm{T}_{94}=\sim 450$ & 2CPCRR & $\begin{array}{c}2000 \mathrm{Nm}^{3} / \mathrm{h}, \\
\mathrm{SV}=3800-81001 / \mathrm{h} ; \mathrm{CMB}\end{array}$ \\
\hline [71] & $\begin{array}{l}\mathrm{Pd} / \mathrm{ZrO}_{2}-\mathrm{MO}_{\mathrm{x}} \\
\mathrm{Pd} / \mathrm{SnO}_{2}-\mathrm{MO}_{\mathrm{x}}\end{array}$ & 800 & 1 & $\begin{array}{l}\sim 300 \\
\sim 300\end{array}$ & $\begin{array}{l}\mathrm{T}_{90}=\sim 500 \\
\mathrm{~T}_{90}=\sim 440\end{array}$ & FR & $\mathrm{SV}=48,0001 / \mathrm{h}$ \\
\hline [22] & $\mathrm{Pd} / \mathrm{Al}_{2} \mathrm{O}_{3}-\mathrm{MO}_{\mathrm{x}}$ & 600 & 0.4 & 300 & $\mathrm{~T}_{90}=410$ & FBTR & $\begin{array}{c}\text { GHSV }=80,0001 / \mathrm{h} ; 4 \% \text { water } \\
\text { GHSV }=160,0001 / \mathrm{h} ; \\
8 \% \text { water; pellets }\end{array}$ \\
\hline [72] & $\begin{array}{c}\mathrm{Pd} / \mathrm{Al}_{2} \mathrm{O}_{3}-\mathrm{ZrSiO}_{4} \\
\mathrm{Pd} / \mathrm{Al}_{2} \mathrm{O}_{3}-\mathrm{SiO}_{2}\end{array}$ & $250-650$ & 1 & $\begin{array}{l}250 \\
270\end{array}$ & $\begin{array}{l}\mathrm{T}_{90}=415 \\
\mathrm{~T}_{90}=447\end{array}$ & FR & GHSV = 5800 1/h; MC \\
\hline [73] & $\mathrm{Pd} / \mathrm{CeO}_{2}$ & $200-560$ & 1 & 200 & $\mathrm{~T}_{100}=300$ & FR & $\begin{array}{c}\text { GHSV }=50,0001 / \mathrm{h} ; \\
10 \% \text { water }\end{array}$ \\
\hline [74] & $\mathrm{Ru}-\mathrm{Re} / \mathrm{Al}_{2} \mathrm{O}_{3}$ & $200-600$ & 0.8 & 200 & $\mathrm{~T}_{95}=525$ & FBR & $\mathrm{GHSV}=60,0001 / \mathrm{h}$ \\
\hline [23] & $\begin{array}{l}\mathrm{Au} / \mathrm{Co}_{3} \mathrm{O}_{4} \\
\mathrm{Au} / \mathrm{Fe}_{2} \mathrm{O}_{3}\end{array}$ & $250-650$ & 0.6 & $\begin{array}{l}290 \\
375\end{array}$ & $\begin{array}{l}\mathrm{T}_{90}=463 \\
\mathrm{~T}_{90}=600\end{array}$ & TMR & $\begin{array}{c}\text { GHSV }=100,0001 / \mathrm{h} ; \\
3 \% \text { water; nanoparticles }\end{array}$ \\
\hline [75] & $\mathrm{Pd} / \mathrm{Sn}_{\mathrm{x}} \mathrm{Zr}_{1-\mathrm{x}} \mathrm{O}_{2}$ & $250-500$ & 1 & 250 & $\mathrm{~T}_{90}=445$ & U-MR & GHSV $=48,0001 / \mathrm{h}$ \\
\hline [76] & $\mathrm{Pd} / \mathrm{LOC}-\mathrm{Zr}$ & $200-500$ & 1 & 200 & $\mathrm{~T}_{90}=380$ & FBMR & $\mathrm{GHSV}=16,000 \mathrm{~mL} /(\mathrm{m} \mathrm{h})$ \\
\hline
\end{tabular}


Table 4. Cont.

\begin{tabular}{|c|c|c|c|c|c|c|c|}
\hline \multirow{2}{*}{ Ref. } & \multirow{2}{*}{ Catalyst } & \multicolumn{2}{|c|}{ Range of } & \multirow{2}{*}{$\begin{array}{l}\mathrm{T}_{\text {ign }} \\
{\left[{ }^{\circ} \mathrm{C}\right]}\end{array}$} & \multirow{2}{*}{$\begin{array}{c}\mathrm{T}_{\mathrm{x}} \\
{\left[{ }^{\circ} \mathrm{C}\right]} \\
\mathrm{x} \text { - Conversion [\%] }\end{array}$} & \multirow{2}{*}{ Reactor } & \multirow{2}{*}{ Experimental Conditions } \\
\hline & & Temp. $\left[{ }^{\circ} \mathrm{C}\right]$ & $\mathrm{CH}_{4}[\mathrm{vol} . \%]$ in Air & & & & \\
\hline [77] & $\mathrm{Pd} / \mathrm{Co}_{3} \mathrm{O}_{4}$ & $250-650$ & $0.5-1$ & 200 & $\mathrm{~T}_{90}=325$ & FR & $\begin{array}{c}\text { WHSV }=30-90 \mathrm{Nl} /\left(\mathrm{g}_{\text {cat }} \mathrm{h}\right) \\
\text { OCF }\end{array}$ \\
\hline [78] & $\mathrm{Pd} / \mathrm{Co}_{3} \mathrm{O}_{4}$ & $200-380$ & 1 & 200 & $\mathrm{~T}_{90}=375$ & FBR & $\begin{array}{l}\text { WHSV }=30,000 \mathrm{~mL} /(\mathrm{g} \mathrm{h}) ; 5 \% \\
\text { water; } 3 \text { types of Pd supports }\end{array}$ \\
\hline [79] & $\mathrm{Cu} / \gamma-\mathrm{Al}_{2} \mathrm{O}_{3}$ & $350-750$ & $0.15-0.3$ & 400 & $\mathrm{~T}_{50}=525-540$ & FBR & $\begin{array}{l}\text { Additional test in fluidized } \\
\text { bed reactor; spheres }\end{array}$ \\
\hline [80] & $\mathrm{Pd} / \mathrm{SiC}$ & $300-550$ & $0.08-0.17$ & 250 & $\mathrm{~T}_{100}=550$ & MTR & $0.5 \mathrm{l} / \mathrm{min}$; foam \\
\hline [81] & Pd/HZSM-5 & 400 & 0.7 & 350 & $\mathrm{~T}_{90}=420$ & FBMR & $\begin{array}{c}\text { GHSV = 100,000 1/h; } \\
30,000 \text { ppm water; zeolite }\end{array}$ \\
\hline [82] & $\mathrm{PdCa} / \mathrm{CeO}_{2}-\mathrm{ND}$ & $200-450$ & 1 & 200 & $\mathrm{~T}_{90}=380-450$ & FBMR & $\mathrm{GHSV}=16,000 \mathrm{~mL} /(\mathrm{g} \mathrm{h})$ \\
\hline [83] & $\mathrm{Pd}-\mathrm{NiCO}_{2} \mathrm{O}_{4} / \mathrm{SiO}_{2}$ & $250-550$ & 1 & 250 & $\mathrm{~T}_{90}=355$ & TR & WHSV $=30,000 \mathrm{~mL} /(\mathrm{g} \mathrm{h})$ \\
\hline [84] & $\begin{array}{l}\mathrm{Pd} / \mathrm{HZSM}-5 \\
\mathrm{PdO} / \mathrm{Al}_{2} \mathrm{O}_{3}\end{array}$ & $175-375$ & 1 & $\begin{array}{l}200 \\
250\end{array}$ & $\begin{array}{l}\mathrm{T}_{100}=280 \\
\mathrm{~T}_{100}=370\end{array}$ & FR & GHSV $=30,0001 / \mathrm{h}$; zeolite \\
\hline [85] & $\begin{array}{c}\mathrm{LaMnO}_{3} \\
\mathrm{La}_{0.8} \mathrm{Sr}_{0.2} \mathrm{MnO}_{3}\end{array}$ & $200-550$ & 0.6 & $\sim 200$ & $\mathrm{~T}_{90}=375$ & $\mathrm{TR}$ & GHSV $=40,0001 / \mathrm{h}$ \\
\hline [86] & $\mathrm{Au} / \mathrm{Fe}_{2} \mathrm{O}_{3}$ & $300-600$ & 1 & 300 & $\mathrm{~T}_{95}=488$ & FBR & $\mathrm{GHSV}=51,0001 / \mathrm{h}$ \\
\hline [87] & $\mathrm{Co}_{3} \mathrm{O}_{4}$ & $200-450$ & 1 & 200 & $\mathrm{~T}_{90}=360$ & No data & GHSV $=168,000 \mathrm{~mL} /\left(\mathrm{g}_{\text {cat }} \mathrm{h}\right)$ \\
\hline [88] & $\begin{array}{l}\mathrm{MgCr}_{2} \mathrm{O}_{4} \\
\mathrm{CoCr}_{2} \mathrm{O}_{4}\end{array}$ & $350-800$ & 1 & $\begin{array}{l}350 \\
380\end{array}$ & $\begin{array}{c}\mathrm{T}_{90}=684 \\
\mathrm{~T}_{90}=736.7\end{array}$ & FBR & $\mathrm{GHSV}=48,000 \mathrm{~mL} /(\mathrm{g} \mathrm{h})$ \\
\hline [89] & $\begin{array}{l}\mathrm{CuCe} \\
\mathrm{CuCeFe}\end{array}$ & $300-500$ & 1 & $\begin{array}{l}\text { No } \\
\text { data }\end{array}$ & $\begin{array}{l}\mathrm{T}_{20}=413 \\
\mathrm{~T}_{25}=440\end{array}$ & FR & $\mathrm{T}_{57}=500$, Tin $=300$ \\
\hline [90] & $\begin{array}{c}\mathrm{Pd} / \mathrm{TS}-1 \\
\mathrm{Pd} / \text { Silicate-1 }\end{array}$ & $300-550$ & 0.7 & $\begin{array}{l}303 \\
305\end{array}$ & $\begin{array}{l}\mathrm{T}_{90}=385 \\
\mathrm{~T}_{90}=410\end{array}$ & FBMR & $\begin{array}{c}\text { GHSV }=100,0001 / \mathrm{h} ; \\
30,000-40,000 \mathrm{ppm} \text { of water } \\
(80-100 \% \text { RH); zeolite }\end{array}$ \\
\hline [91] & $\mathrm{CuO}-\mathrm{CeO}_{2}$ & $300-600$ & 0.1 & 300 & $\mathrm{~T}_{90}=575$ & FR & WHSV $=78,000 \mathrm{~mL} /(\mathrm{g} \mathrm{h})$ \\
\hline [92] & $(0.5-2 \%) \mathrm{Pd} / \mathrm{Al}_{2} \mathrm{O}_{3}$ & $250-550$ & $0.5-1$ & 255 & $\mathrm{~T}_{90}=390$ & FR & $\begin{array}{l}\text { GHSV }=4500-70001 / \mathrm{h} ; \\
\text { Metal monolith }\end{array}$ \\
\hline [93] & $\begin{array}{c}\mathrm{PdO}-\mathrm{Pt} / \alpha-\mathrm{Al}_{2} \mathrm{O}_{3} \\
\mathrm{PdO} / \alpha-\mathrm{Al}_{2} \mathrm{O}_{3}\end{array}$ & 350 & 0.5 & $\begin{array}{l}\text { No } \\
\text { data }\end{array}$ & $\begin{array}{l}\mathrm{T}_{97}=350 \\
\mathrm{~T}_{87}=350\end{array}$ & FBR & $\mathrm{GHSV}=18,0001 / \mathrm{h}$ \\
\hline [94] & $\mathrm{Pd} / \mathrm{NiO}$ & $330-730$ & 1 & $\sim 280$ & $\mathrm{~T}_{90}=748$ & FR & GHSV $=100,0001 / \mathrm{h}$ \\
\hline [17] & $1 \mathrm{wt} \% \mathrm{Pd} \mathrm{Al}_{2} \mathrm{O}_{3}$ & $250-500$ & 0.7 & $\sim 250$ & $\mathrm{~T}_{90}=45$ & FR & $\begin{array}{l}\text { GHSV }=100,0001 / \mathrm{h} \text {; test } \\
\text { with water and dust mine }\end{array}$ \\
\hline [95] & $\begin{array}{c}\mathrm{Co}_{2} \mathrm{MnO}_{4} \\
\mathrm{Pd} / \mathrm{Co}_{2} \mathrm{MnO}_{4}\end{array}$ & $200-475$ & 1 & $\begin{array}{l}\sim 250 \\
\sim 225\end{array}$ & $\begin{array}{l}\mathrm{T}_{90}=373 \\
\mathrm{~T}_{90}=324\end{array}$ & FBR & $\begin{array}{l}\text { WHSV }=15,000- \\
120,000 \mathrm{~mL} /(\mathrm{g} \mathrm{h})\end{array}$ \\
\hline [96] & $\mathrm{Pd} / \mathrm{HNT}$ & $200-450$ & 1 & $\sim 250$ & $\mathrm{~T}_{100}=375$ & FBMR & $\mathrm{GHSV}=72,000 \mathrm{~mL} /(\mathrm{g} \mathrm{h})$ \\
\hline
\end{tabular}

The structure of the methane molecule makes it difficult to start the combustion reaction. A good catalyst should be characterized by high catalytic activity in oxidation reactions, high thermal stability, significant lifetime, and high resistance to catalytic poisons. It is difficult to find an ideal catalyst and very often, some modifications are made to adjust its applicability in a given reaction. The addition of oxides can increase the stability of the catalyst, protect against the migration of particles, or increase its activity [91].

Noble metal $(\mathrm{Pd}, \mathrm{Pt}, \mathrm{Au}$, etc.) catalysts have high activity, but on the other hand, they have poor stability [97], tendency to sintering, and unfortunately high cost [98]. Many investigations and studies are focused on catalyst modifications to enhance the durability of catalysts and activity, resistance against water and other unfavorable components of VAM [17].Based on the literature review, it was revealed that Pd is the most active of the noble metals and its addition increased the activity of the catalyst [83] and provided good thermostability of the active phase [99]. It is known that the transition metal oxide in high temperature is deactivated. In the case of Pd, its oxidized form (PdO) decomposes into $\mathrm{Pd}$ metal in the range $650-850^{\circ} \mathrm{C}$, depending on $\mathrm{O}_{2}$ partial pressure and reactive gas mixture composition. Reduction of the $\mathrm{PdO}$ to $\mathrm{Pd}$ has a negative effect on the catalytic reaction, causing a lowering conversion. A previous level of activity can be restored upon re-oxidation of $\mathrm{Pd}$ to $\mathrm{PdO}$. The re-oxidation of Pd metal is related to the nature of the support [100]. 
Role of Support

Catalytic performance is strongly dependent on the nature of the support $[75,95,101]$ and depends on the interaction between the support and active phases [81]. The comparison of the influence of additives in catalysts by various authors on a chemical reaction is not easy. These catalysts were obtained by various methods and tested in different conditions, both processes and reactors. Only the works aimed at studying the influence of catalyst modification on the efficiency of the combustion reaction showed the real effects. It was shown that different additives such as $\mathrm{La}_{2} \mathrm{O}_{3}$ and $\mathrm{SiO}_{2}$ or $\mathrm{ZrSiO}_{4}$ into washcoat $\mathrm{Al}_{2} \mathrm{O}_{3}$ for the Pd catalyst and enhance the conversion of methane and thermal resistance [72]. In the article [102], it is indicated that $\mathrm{Pd}$ on $\mathrm{Al}_{2} \mathrm{O}_{3}$ support had a higher activity than Pd-Pt or Pd-Pt-Rh on the same support. Activity of Pd over alumina, zirconia, and anatase-support in [101] for the same temperature was different. Modification by Ca addition led to high oxygen mobility and strong Pd support interaction [82]. The authors of [94] indicated that even small amounts of metal oxides enhanced the activity of Pd. Out of all the metal oxides tested, the best effect was achieved for $\mathrm{NiO}$. The addition of $\mathrm{NiO}$ significantly lowered the temperature (around $200^{\circ} \mathrm{C}$ ) at which $90 \%$ methane conversion was obtained. The authors suggest that the addition of $\mathrm{NiO}$ to $\mathrm{Pd}$ ensures a higher level of oxygen concentration on its surface, resulting in an elevation of activity. The Au catalyst was less interesting for the purpose of VAM oxidation. The tests carried out on $\mathrm{Co}_{3} \mathrm{O}_{4}$ and $\mathrm{Fe}_{2} \mathrm{O}_{3}$ supports showed big differences in ignition temperature and temperature in which high methane conversion is guaranteed. It is interesting that the catalysts that contained only $\mathrm{Co}_{3} \mathrm{O}_{4}$ and $\mathrm{Fe}_{2} \mathrm{O}_{3}$ without $\mathrm{Au}$ particles were characterized as having slightly better activation, but a bad water resistance. In [95], it was mentioned that the type of the support may reduce the size of the Pd particles, improve the mobility of Pd species, and lower the binding energy of surface oxygen. The authors checked the active PdO embedded on a variety of spinel $\mathrm{Co}_{2} \mathrm{MO}_{4}(\mathrm{M}=\mathrm{Co}, \mathrm{Mn}, \mathrm{Al})$ supports with similar textural properties, but different surface chemistries. The best activity was achieved for $\mathrm{Pd} / \mathrm{Co}_{2} \mathrm{MnO}_{4}$. The effect of the support on the activity can be seen by comparing the temperature values that are necessary to achieve the same conversion. The experiments showed that for $80 \%$ conversion $\mathrm{Pd} / \mathrm{Co}_{2} \mathrm{MnO}_{4}$ catalyst need about $300{ }^{\circ} \mathrm{C}$ and $\mathrm{Pd} / \mathrm{Co}_{2} \mathrm{AlO}_{4}$ needs $475{ }^{\circ} \mathrm{C}$.

In addition, the methods of preparing the same two catalysts also have a significant influence on their properties. Methods such as impregnation or the deposition-precipitation used in preparing the $\mathrm{Pd} / \mathrm{CeO}_{2}[73]$ catalyst influenced its activity. The test showed that the reaction started at a completely different temperature, different by about $200{ }^{\circ} \mathrm{C}$. Total conversion for $\mathrm{Pd} / \mathrm{CeO}_{2}$ prepared by the deposition-precipitation method was obtained at $300{ }^{\circ} \mathrm{C}$ and the catalyst was characterized by exceptional stability and resistance to water. Examples of other palladium catalysts that ensure a complete conversion of VAM at comparatively low temperatures are $\mathrm{Pd}-\mathrm{NiCO}_{2} \mathrm{O}_{4} / \mathrm{SiO}_{2}$ [83] and $\mathrm{Pd} / \mathrm{HZSM}-5$ [84]. In the case of the first one, the total conversion was achieved at $378{ }^{\circ} \mathrm{C}$. The authors of [83] emphasized that the catalyst had a good thermal stability achieved by the distribution of $\mathrm{Pd}-\mathrm{NiCO}_{2} \mathrm{O}_{4}$ on $\mathrm{SiO}_{2}$ in this way, where nanoparticles are separated from each other by another component. In the case of Pd/HZSM-5, as reported in [84], the total conversion was obtained at ca $280^{\circ} \mathrm{C}$.

\section{Poison Resistance and Stability Tests}

One of the requirements for a catalyst in VAM utilization is its resistance to water and sulfur compounds. In many cases, the authors did not provide a humidity test. It was experimentally proven that water has a significant influence on the activity of catalysts. Water inhibits the rate of Pd re-oxidation, which causes limited oxygen mobility on the support [90]. The attempts carried out on the Cu catalyst showed that the deactivation of the catalyst under the influence of water appears to be reversible. A similar effect was noticed in [103] for $\mathrm{Pd} / \mathrm{Al}_{2} \mathrm{O}_{3}$ where the inhibition process was partially reversible above $400{ }^{\circ} \mathrm{C}$. In [104], it was shown that dispersion of the Pd phase also influences the deactivation of the catalyst, which stays in contact with water. The lower dispersion of 
$\mathrm{Pd}$ and the higher the water concentration in the feed stream, the stronger the inhibiting effect observed. Although $\mathrm{Cu}$ has a stronger water resistance than the Pd and Pt catalysts, further detailed research of regeneration tests revealed that multicycle water adsorption and desorption influenced the activity of the catalyst. This means that its activity does not recover to its initial level before water supply. Over time, the measured conversion decreases [24]. Other experiments testing the effect of water on Pd/HZSM-5 catalysts during long-term working showed a gradual deactivation of the catalyst caused by a dealumination and agglomeration of palladium on the surface of the HZSM-5 [81]. A similar conclusion can be drawn on the basis of the study in [84], where tests of Pd/HZSM5 revealed that the catalyst was unstable in contact with water. Another support, TS-1 zeolite [90], presented excellent stability under a humid feed condition by keeping over $90 \%$ methane conversion during $100 \mathrm{~h}$ time on stream. The authors in [95] indicated a high catalytic activity at $97 \sim 98 \%$ under 5 vol. $\%$ of water in tests with the spinel $\mathrm{Pd} / \mathrm{Co}_{2} \mathrm{MnO}_{4}$ catalyst. The presence of sulfur compounds can significantly limit the application of a catalyst. The experimental study [105] showed that the Pd catalyst is quickly deactivated, especially at a lower temperature and higher concentration of $\mathrm{SO}_{2}$.

Another issue of the tested catalysts are very short stability tests. In laboratory conditions, they usually do not last longer than a few to several dozen hours [74-77,80]. In many cases, the long stability test showed deactivation of the catalyst. In [74], the authors even indicated a $20 \%$ drop in methane conversion at $500{ }^{\circ} \mathrm{C}$ in $80 \mathrm{~h}$ of testing. Research on improving the stability of the $\mathrm{PdO} / \alpha-\mathrm{Al}_{2} \mathrm{O}_{3}$ catalyst by adding $\mathrm{Pt}$ in [93] was also carried out over a short period of time (i.e., about $6 \mathrm{~h}$. The time of $1900 \mathrm{~h}$ of the mentioned test carried out in [90] seems to be appropriate, especially when the catalyst presented a good condition with slight dispersion changes obtained by the anchoring role of $\mathrm{Ti}$, which prevents migration and agglomeration of Pd. Noteworthy is the work by [17], where the authors presented the results of long-term catalyst stability tests in the presence of water and mine dust. The tests were carried out with the $\mathrm{Pd} / \mathrm{Al}_{2} \mathrm{O}_{3}$ catalyst. The stability test with dry gases were conducted for $1600 \mathrm{~h}$. The experiments under wet conditions were run continuously for $1150 \mathrm{~h}$. The test showed that keeping $90 \%$ methane conversion needed a higher temperature in a wet environment. The tests with dust revealed a higher fluctuation in conversion levels and temperature of the bed than in the experiments without dust. The inhibitory effect of VAM dust is most likely due to the presence of chloride ions on the surface of the catalyst, which appear on the catalyst during the experiments in the presence of mine dust.

\section{Catalysts Application}

The next step in seeking a suitable catalyst should include its tests in the target reactor with a specific bed geometry. Tests of the catalysts in demonstration devices are described below.

VAM utilization, as reported in the literature $[11,18,26,59,60,106-116]$, can be realized in catalytic flow reversal reactors CFRR. It is most likely that the Boreskov Institute of Catalysis [110] was the first that tested VAM combustion in CFRR. Such studies, for at least several years, have also been carried out among others by the Canadian research center CANMET. The authors of [49] tested the installation with a capacity of $54,000 \mathrm{Nm}^{3} / \mathrm{h}$ at a commercial scale in the laboratory. The solution on an industrial scale has not been implemented. Catalytic technologies dedicated for VAM mitigation are still being developed. Due to difficult conditions in the reactor, the tested catalytic beds were not as stable as they should be. The attempts carried out revealed huge problems with the resistance of catalysts at high temperature in reactors with reversal flow [117-119]. The intensive heat exchange in reverse reactors due to the formation of the so-called "heat wave", shows that even in low concentrations, the maximum temperature in CFRR differed no more than about $200{ }^{\circ} \mathrm{C}$ from temperatures in TFRR. In this way, CFRR zones are created in which the catalyst temperature reaches or even exceeds $800^{\circ} \mathrm{C}$ [60], even for a methane concentration of $0.22 \mathrm{vol} . \%$, which may lead to its deactivation or even destruction. It 
should be emphasized that high temperature also leads to homogeneous combustion in the gas phase in CFRR [120,121].

Attempts to use cheaper catalysts (e.g., $\mathrm{MnO}_{x}[110,117,118,122]$ or $\mathrm{Cu}-\mathrm{Cr}$ [123]) tested in the project [124] also confirmed the same problem. The authors in [122] indicated that a manganese oxide-alumina catalyst enabled working at temperatures up to $1000{ }^{\circ} \mathrm{C}$. Authors of [51] conducted a mathematical simulation of CFRR for VAM flow of $30,000 \mathrm{~m}^{3}$ STP $/ \mathrm{h}$, with the catalyst data taken from [122]. The results of the simulation indicate that temperature inside the reverse flow reactor might be too high for the $\mathrm{MnO}_{\mathrm{x}}$ catalysts themselves. Many studies in this area are based on using noble metals: Pt-Pd [60,102], Pd [102,114,116,117,125], and Pt-Pd-Rh [102]. As stated in [11], the maximum continuous catalyst bed temperature was $750{ }^{\circ} \mathrm{C}$ for a monolith reactor catalyst containing $\mathrm{Pd} / \mathrm{Rh}$ or $\mathrm{Pt} / \mathrm{Rh}$. In the case of changes in methane concentration to higher values, the temperature could even achieve $850-920{ }^{\circ} \mathrm{C}$. It was also noted that for a similar $\mathrm{Pd} / \mathrm{Rh}$ and $\mathrm{Pt} / \mathrm{Rh}$ catalyst but with about twice as high $\mathrm{Pd}$ load, the value increased to $950^{\circ} \mathrm{C}$ (for higher methane conc. to $1050^{\circ} \mathrm{C}$ ). It seems that using the $\mathrm{Pd}$ catalyst or another noble metal catalyst in different combinations is possible when applied only for a lower methane concentration in VAM not exceeding 0.8 vol.\%. A comparison of the conversion for the same temperature showed that the greater amount of $\mathrm{Pd}$, the higher the methane conversion [82]. Moreover, the Pd content on the $\mathrm{Al}_{2} \mathrm{O}_{3}$ carrier should be in the range of 0.5 to $2 \%$ [92]. In [51], it was indicated that the estimated amount of $\mathrm{Pd}$ in the catalyst containing $0.5 \% \mathrm{Pd}$ for CFRR, which processes $500,000 \mathrm{~m}^{3} / \mathrm{h}$ of ventilation air with $0.8 \mathrm{vol} . \% \mathrm{VAM}$, was $370 \mathrm{~kg}$.

The amount of methane strongly affects the temperature profile in the reactor [11]. The authors in [114] compared the reactions of the catalytic oxidation of methane on $\mathrm{Pd} / \mathrm{Al}_{2} \mathrm{O}_{3}$ in CFRR for two packed (particle) and structured beds. The authors paid attention to the possible occurrence of zones with very high temperature. Simulations revealed that the higher surface velocity and thus higher methane molar flow rate promoted increases to the temperature above the values, leading to deactivation of the catalyst. Due to catalyst protection maintaining lower surface velocities, the bed temperature in the CFRR should stabilize. Furthermore, many methane combustion catalysts have been tested in many reactor solutions, where the Pd catalyst is taken into account.

Unpredictable changes in the VAM composition forces an appropriate system control, which prevents the reactor from overheating and extinction [59]. Due to high water concentration in VAM, the catalyst also needs protection from its inhibitory effect. The influence of water on the performance of the catalyst in CFRR is presented in [116]. It has been noted that the presence of water reduces the range of stable operating conditions of CFRR. This situation requires reducing the switching time or increasing the methane concentration in the feed stream to keep the work of the reactor stable. The novel approach to trap water from the feed stream of VAM was proposed in [18]. The CFRR was modified by the addition of an adsorbent layer, which prevents water from entering the catalyst layer. The experiments carried out on the lab-scale with $0.18-0.54$ vol.\% of methane and 0.021-0.024 molar fraction of water showed that additional layers of adsorbent effectively separated water. The simulations of larger unit of CFRR $\left(45 \mathrm{~m}^{3} / \mathrm{s}\right.$, methane conc. 0.3 vol. $\%$ and $5 \%$ of water) also showed that the proposed adsorbent was able to self-regenerate [126]. Additionally, the cost analysis indicated that integrated water separation reduced the total cost of the reactor. A similar method of catalyst protection from sulfur compounds was proposed and tested in [115].

An interesting option in catalytic VAM oxidation was proposed by COMET ${ }^{\mathrm{TM}}$ [16]. It is a flow reactor with a bimetallic PtPd catalyst bed that is better able to deal with possible sulfur compounds if they occur in VAM. The reactor was tested for methane concentration of $0.1-0.8$ vol. $\%$. Two-year studies of the catalyst operation stability were performed. The sustained high conversion of methane in all test periods is promising in terms of implementing this technology in areal environment. According to [16], depending on methane concentration, the generated energy will keep the reactor working or it will allow recovering the energy for other uses. 
A new proposal for VAM catalytic oxidation is presented in [127]. As one of the first in the world, the large installation was studied under real conditions in the mine. The tested installation was designed for a flow of 3000-3500 $\mathrm{m}^{3} / \mathrm{h}$. The concentration of methane in the VAM was $0.1-0.3 \%$ and higher concentrations of the combustible component were obtained by mixing VAM with an additional methane stream. The flow reactor was filled with two types of catalysts: Pd on a monolithic metallic support and Pd on an $\mathrm{Al}_{2} \mathrm{O}_{3}$ support. The experiments with a flow rate of $2500 \mathrm{~m}^{3} / \mathrm{h}$ showed that the reactor was not able to work stably when the methane concentration in VAM was lower than $0.615 \%$.

Among the latest works related to catalytic VAM oxidation, it is worth mentioning a paper [128] that proposed a completely different approach to the utilization of VAM. The key point of their solution was underground catalytic methane oxidation in a three-channel internal-recirculation type reactor. The reactor concept assumes that it will consist of stacked reactor elements, each consisting of three channels. One element involves an inlet channel, a central channel with the catalyst, and an outlet channel. The inlet and outlet channel are filled with metallic foam, while the central part contains a monolith with a catalytic washcoat. It should be noted that at the present stage, the idea of this reactor was analyzed using mathematical modeling. The results of this analysis showed that it is possible to physically create such a unit for operations under the required operating conditions.

Another novel concept concerning methane oxidation from mixtures where its concentration is lower than $0.3 \mathrm{vol} \%$ (and even at hundreds of ppm levels) was tested by the CSIRO [129]. This technology is based on photocatalytic methane oxidation into carbon dioxide at ambient temperature and pressure conditions. This idea is at the phase of laboratory tests. The results show that the VAM mixture can be oxidized in the process of photocatalysis, but the reaction rate is low. Therefore, photocatalytic oxidation of VAM is a new idea, presenting a new approach to the utilization of dilute methane, but the knowledge of this photocatalytic reaction mechanism is limited. On other hand, the lack of information regarding the reaction mechanism may result in increased interest and research into this technology.

Catalytic methods are still under development. However, the lack of tested industrial implementations is unsatisfactory for the mining industry in countries where catalytic solutions seem to be the only solution to the methane emission problem. In addition to the technology being developed, an important aspect is also the profitability of the considered technology. Many countries are facing changes in their greenhouse gas emissions regulations and the emission penalties of methane. Methane, as a greenhouse gas, is not included in the EU Emission Trading System (EU ETS) fee system. However, this situation will change, which will force mining to look for solutions to reduce VAM emissions. The worst situation is in countries where the amount of methane in VAM does not allow for the use of existing solutions. In Poland, the fee for methane emissions from hard coal mines is about PLN 150,000 PLN annually, which is $0.2 \%$ of the general costs associated with environmental fees. Experts estimate that in a situation where the fee for the emission of a ton of methane will be determined based on the greenhouse potential of this gas, the mines will be burdened with costs of up to 300 million PLN per year, which would undoubtedly significantly contribute to the deterioration of the national mining industry. Avoiding such high fees forces the development of advanced catalytic methods and their rapid implementations. Another point should be mentioned here. Catalytic solutions are based and, as shown by scientific research, will be based on Pd catalysts. The enormous amounts of Pd needed to make the catalyst significantly increase the investment costs. The economic analysis carried out in [117] showed that the payback time for VAM combustion on a palladium catalyst, due to its cost, would be about seven years (i.e., longer than the expected operation time of such a catalyst). Moreover, for a given solution to be beneficial from an economic point of view, the investment cost must be lower than the value of the penalties imposed for the issue. 


\section{Conclusions}

The authors of this article reviewed the literature data that corresponded to the problem of methane utilization from coal mine ventilation air and abatement technologies that have a reliable potential to be implemented into the industry. The biggest problem with VAM disposal is its variability in terms of flow, methane concentration, dust, high humidity, and possible presence of other gaseous pollutants. The most technologically advanced implemented solutions are based on the thermal oxidation method in TFRR. These installations operate at higher methane concentrations than that found in the average ventilation shaft. Higher concentrations in the feed streams are achieved by adding additional fuel. When the VAM concentration is high enough, a surplus of heat energy is produced, which can be converted into other uses.

The real challenge is the disposal of mixtures with a very low concentration of methane (i.e., less and much less than $0.4 \mathrm{vol} . \%$ ) in mines where it is not possible to use their own additional supplementation with VAM in order to increase its calorific value. In such situations, a technology based on VAM enrichment could help. However, it should be noted that a single ventilation shaft emits such huge amounts of ventilation air that no technology available today is able to process it. The greatest potential is visible in catalytic technologies. Research shows that the technologies being developed are increasingly effective at the oxidation of low concentration VAM. However, the catalysts used not only have to be resistant to high temperatures and difficult working conditions, but their industrial application must be profitable. Most of the studied catalysts were tested under laboratory conditions with pure gases. It is necessary to conduct research on a larger scale in real, target conditions. It should be highlighted that the presence in VAM of two contaminants: sulfur compounds and water may enhance the deactivation of the catalyst used. In the case of the flow reversal reactor, the lifetime of any catalyst was much lower than that of the inert heat accumulating packing in TFRR. The widely tested Pd catalysts had good activity in different configurations. In many cases, the long stability test showed the deactivation of the catalyst, which could even drop $20 \%$ in methane conversion at $500{ }^{\circ} \mathrm{C}$ in $80 \mathrm{~h}$ of testing. It is true that the expensive catalyst components significantly increase the investment and operating costs of large installations, especially if the installation has to process several hundred thousand cubic meters of coal mine ventilation air. There is still much to do in the area of VAM disposal, especially when the amount of methane in VAM is very small. The developing catalytic technologies are still immature to match the scale of the thermal methods. Photocatalytic experiments have shown the possibility of methane oxidation at ambient temperature and pressure conditions, even for low concentrations such as hundreds of ppm. The potential of the newly developing technology may be promising due to the possibility of using it for methane destruction from uncontrolled sources, where any known technology cannot be applied such as atmospheric methane. However, due to the limitation of the photocatalytic reaction rate compared to other oxidation methods, this technology still requires further research.

Author Contributions: Visualization, writing—review and editing, A.P.-K.; Visualization, writingoriginal draft, M.S. All authors have read and agreed to the published version of the manuscript.

Funding: This research received no external funding.

Conflicts of Interest: The authors declare no conflict of interest.

\section{References}

1. Song, Y.; Liu, S.B.; Zhang, Q.; Tao, M.X.; Zhao, M.J.; Hong, F. Coalbed methane genesis, occurrence and accumulation in China. Pet. Sci. 2012, 9, 269-280. [CrossRef]

2. Cashdollar, K.L.; Zlochower, I.A.; Green, G.M.; Thomas, R.A.; Hertzberg, M. Flammability of methane, propane, and hydrogen gases. J. Loss Prev. Process. Ind. 2000, 13, 327-340. [CrossRef]

3. Su, S.; Chen, H.W.; Teakle, P.; Xue, S. Characteristics of coal mine ventilation air flows. J. Environ. Manag. 2008, 86, 44-62. [CrossRef] [PubMed] 
4. Gosiewski, K.; Pawlaczyk, A.; Jaschik, M. Energy recovery from ventilation air methane via reverse-flow reactors. Energy 2015, 92, 13-23. [CrossRef]

5. Singh, H.; Mallick, J. Utilization of Ventilation Air Methane in Indian Coal Mines: Prospects and Challenges. Glob. Chall. Policy Framew. Sustain. Dev. Min. Mineral. Foss. Energy Resour. (Gcpf2015) 2015, 11, 56-62. [CrossRef]

6. Yusuf, R.O.; Noor, Z.Z.; Abba, A.H.; Abu Hassan, M.A.; Din, M.F.M. Methane emission by sectors: A comprehensive review of emission sources and mitigation methods. Renew. Sustain. Energy Rev. 2012, 16, 5059-5070. [CrossRef]

7. Kholod, N.; Evans, M.; Pilcher, R.C.; Roshchanka, V.; Ruiz, F.; Cote, M.; Collings, R. Global methane emissions from coal mining to continue growing even with declining coal production. J. Clean. Prod. 2020, 256, 120489. [CrossRef]

8. Derwent, R.G. Global Warming Potential (GWP) for Methane: Monte Carlo Analysis of the Uncertainties in Global Tropospheric Model Predictions. Atmosphere 2020, 11, 486. [CrossRef]

9. Global Greenhouse Gas Emissions Data. Available online: https://www.epa.gov/ghgemissions/global-greenhouse-gasemissions-data (accessed on 15 June 2021).

10. Wang, W.; Ren, J.D.; Li, X.J.; Li, H.B.; Li, D.Y.; Li, H.M.; Song, Y. Enrichment experiment of ventilation air methane (0.5\%) by the mechanical tower. Sci. Rep. 2020, 10, 1-10. [CrossRef]

11. Su, S.; Agnew, J. Catalytic combustion of coal mine ventilation air methane. Fuel 2006, 85, 1201-1210. [CrossRef]

12. Holmes, R.I. Mitigating Ventilation Air Methane Cost-Effectively from a Colliery in Australia. J. Appl. Eng. Sci. 2016, 6, 41-50. [CrossRef]

13. Singh, A.K.; Kumar, J. Fugitive methane emissions from Indian coal mining and handling activities: Estimates, mitigation and opportunities for its utilization to generate clean energy. In Proceedings of the 5th International Conference on Advances in Energy Research (ICAER), IIT Bombay, Mumbai, India, 15-17 December 2015; pp. 336-348.

14. Baris, K. Assessing ventilation air methane (VAM) mitigation and utilization opportunities: A case study at Kozlu Mine, Turkey. Energy Sustain. Dev. 2013, 17, 13-23. [CrossRef]

15. Dreger, M.; Kedzior, S. Methane emissions and demethanation of coal mines in the Upper Silesian Coal Basin between 1997 and 2016. Environ. Socio-Econ. Stud. 2019, 7, 12-23. [CrossRef]

16. Hinde, P.; Mitchell, I.; Riddell, M. COMET (TM) —A New Ventilation Air Methane (VAM) Abatement Technology. Johns. Matthey Technol. Rev. 2016, 60, 211-221. [CrossRef]

17. Setiawan, A.; Friggieri, J.; Kennedy, E.M.; Dlugogorski, B.Z.; Stockenhuber, M. Catalytic combustion of ventilation air methane (VAM) - Long term catalyst stability in the presence of water vapour and mine dust. Catal. Sci. Technol. 2014, 4, 1793-1802. [CrossRef]

18. Fernandez, J.; Marin, P.; Diez, F.V.; Ordonez, S. Experimental demonstration and modeling of an adsorption-enhanced reverse flow reactor for the catalytic combustion of coal mine ventilation air methane. Chem. Eng. J. 2015, 279, 198-206. [CrossRef]

19. Bae, J.S.; Su, S.; Yu, X.X.; Yin, J.J.; Villella, A.; Jara, M.; Loney, M. Site Trials of Ventilation Air Methane Enrichment with Two-Stage Vacuum, Temperature, and Vacuum Swing Adsorption. Ind. Eng. Chem. Res. 2020, 59, 15732-15741. [CrossRef]

20. Tremain, P.; Maddocks, A.; Moghtaderi, B. Stone Dust Looping for Ventilation Air Methane Abatement: A 1 m(3)/s Pilot-Scale Study. Energy Fuels 2019, 33, 12568-12577. [CrossRef]

21. Bae, J.S.; Jin, Y.G.; Huynh, C.; Su, S. Biomass-derived carbon composites for enrichment of dilute methane from underground coal mines. J. Environ. Manag. 2018, 217, 373-380. [CrossRef]

22. Liu, Y.; Wang, S.; Gao, D.; Sun, T.; Zhang, C.; Wang, S. Influence of metal oxides on the performance of $\mathrm{Pd} / \mathrm{Al}_{2} \mathrm{O}_{3}$ catalysts for methane combustion under lean-fuel conditions. Fuel Process. Technol. 2013, 111, 55-61. [CrossRef]

23. Setiawan, A.; Kennedy, E.M.; Dlugogorski, B.Z.; Adesina, A.A.; Stockenhuber, M. The stability of $\mathrm{Co}_{3} \mathrm{O}_{4}, \mathrm{Fe}_{2} \mathrm{O}_{3}, \mathrm{Au} / \mathrm{Co}_{3} \mathrm{O}_{4}$ and $\mathrm{Au} / \mathrm{Fe}_{2} \mathrm{O}_{3}$ catalysts in the catalytic combustion of lean methane mixtures in the presence of water. Catal. Today 2015, 258, 276-283. [CrossRef]

24. Haojie, G.; Zhongqing, Y.; Jingyu, R.; Li, Z.; Yunfei, Y.; Mingnv, G. Low-concentration methane combustion over a Cu/g- $\mathrm{Al}_{2} \mathrm{O}_{3}$ catalyst: Effects of water. RSC Adv. 2015, 5, 18915-18921.

25. UNFCCC. Text of the Kyoto Protocol. Available online: https://unfccc.int/process-and-meetings/the-kyoto-protocol/what-isthe-kyoto-protocol/kyoto-protocol-targets-for-the-first-commitment-period (accessed on 15 June 2021).

26. Su, S.; Beath, A.; Guo, H.; Mallett, C. An assessment of mine methane mitigation and utilization technologies. Prog. Energy Combust. Sci. 2005, 31, 123-170. [CrossRef]

27. Deng, L.; Wang, Y.; Wu, S.; Che, D. Utilization of combustible waste gas as a supplementary fuel in coal-fired boilers. Int. J. Energy Res. 2018, 42, 1677-1692. [CrossRef]

28. Warmuziński, K.; Jaschik, M.; Olejnik, S.; Tańczyk, M.; Jaschik, J. Analiza kosztów utylizacji kopalnianego powietrza wentylacyjnego w produkcji ciepła i energii elektrycznej. Chem. Inżynieria Ekol. 2004, 11, 242-250.

29. SU, S.; YU, X. Progress in developing an innovative lean burn catalytic turbine technology for fugitive methane mitigation and utilization. Front. Energy 2011, 5(2), 229-235. [CrossRef]

30. Yang, X.; Liu, Y.S.; Li, Z.Y.; Zhang, C.Z.; Xing, Y. Vacuum Exhaust Process in Pilot-Scale Vacuum Pressure Swing Adsorption for Coal Mine Ventilation Air Methane Enrichment. Energies 2018, 11, 1030. [CrossRef]

31. Su, S.; Yu, X.X. A 25 kWe low concentration methane catalytic combustion gas turbine prototype unit. Energy 2015, 79, 428-438. [CrossRef] 
32. Yang, Y.; Wu, Y.J.; Liu, H.Q.; Ribeiro, A.M.; Li, P.; Yu, J.G.; Rodrigues, A.E. Enrichment of ventilation air methane by adsorption with displacement chromatography technology: Experiment and numerical simulation. Chem. Eng. Sci. 2016, 149, 215-228. [CrossRef]

33. Li, Q.Z.; Lin, B.Q.; Yuan, D.S.; Chen, G.M. Demonstration and its validation for ventilation air methane (VAM) thermal oxidation and energy recovery project. Appl. Therm. Eng. 2015, 90, 75-85. [CrossRef]

34. He, X.Z.; Lei, L.F. Optimizing methane recovery: Techno-economic feasibility analysis of N-2-selective membranes for the enrichment of ventilation air methane. Sep. Purif. Technol. 2021, 259, 118180. [CrossRef]

35. Du, J.W.; Li, H.J.; Wang, L.G. Thermodynamic stability conditions, methane enrichment, and gas uptake of ionic clathrate hydrates of mine ventilation air. Chem. Eng. J. 2015, 273, 75-81. [CrossRef]

36. Bałys, M.; Szczurowski, J.; Czepirski, L. Adsorption technology for ventilation air methane enrichment; Agencja WydawniczoPoligraficzna ART-TEKST: Krakow, Poland, 2016; pp. 253-257.

37. Bae, J.S.; Su, S.; Yu, X.X. Enrichment of Ventilation Air Methane (VAM) with Carbon Fiber Composites. Environ. Sci. Technol. 2014, 48, 6043-6049. [CrossRef]

38. Ursueguia, D.; Diaz, E.; Ordonez, S. Densification-Induced Structure Changes in Basolite MOFs: Effect on Low-Pressure $\mathrm{CH}(4)$ Adsorption. Nanomaterials 2020, 10, 1089. [CrossRef] [PubMed]

39. Hu, G.P.; Zhao, Q.H.; Tao, L.F.; Xiao, P.; Webley, P.A.; Li, K.G. Enrichment of low grade $\mathrm{CH}_{4}$ from N-2/ $\mathrm{CH}_{4}$ mixtures using vacuum swing adsorption with activated carbon. Chem. Eng. Sci. 2021, 229, 116152. [CrossRef]

40. Zhu, T.; Wang, R.N.; Zhang, X.; Han, Y.W.; Bian, W.J.; Ma, Y.; Xue, M. Enrichment and Separation of Methane Gas by Vacuum Pressure Swing Adsorption. Adsorpt. Sci. Technol. 2021, 2021, 1-12. [CrossRef]

41. Liu, B.; Smit, B. Molecular Simulation Studies of Separation of $\mathrm{CO}_{2} / \mathrm{N}_{2}, \mathrm{CO}_{2} / \mathrm{CH}_{4}$, and $\mathrm{CH}_{4} / \mathrm{N}_{2}$ by ZIFs. J. Phys. Chem. C 2010, 114, 8515-8522. [CrossRef]

42. Cavenati, S.; Grande, C.A.; Rodrigues, A.E. Separation of Methane and Nitrogen by Adsorption on Carbon Molecular Sieve. Sep. Sci. Technol. 2005, 40, 2721-2743. [CrossRef]

43. Zhang, J.; Qu, S.; Li, L.; Wang, P.; Li, X.; Che, Y.; Li, X. Preparation of Carbon Molecular Sieves Used for $\mathrm{CH}_{4} / \mathrm{N}_{2}$ Separation. J. Chem. Eng. Data 2018, 63, 1737-1744. [CrossRef]

44. Majumdar, B.; Bhadra, S.J.; Marathe, R.P.; Farooq, S. Adsorption and Diffusion of Methane and Nitrogen in Barium Exchanged ETS-4. Ind. Eng. Chem. Res. 2011, 50, 3021-3034. [CrossRef]

45. Ouyang, S.; Xu, S.; Song, N.; Jiao, S. Coconut shell-based carbon adsorbents for ventilation air methane enrichment. Fuel 2013, 113, 420-425. [CrossRef]

46. Bae, J.S.; Su, S.; Yu, X.X. Two-Stage Enrichment of Ventilation Air Methane with Vacuum, Temperature, and Vacuum Swing Adsorption (VTVSA) Processes. Ind. Eng. Chem. Res. 2019, 58, 21700-21707. [CrossRef]

47. Matros, Y.S.; Bunimovich, G.A. Reverse-Flow Operation in Fixed Bed Catalytic Reactors. Catal. Rev.-Sci. Eng. 1996, $38,1-68$. [CrossRef]

48. Zagoruiko, A.N.; Bobrova, L.; Vernikovskaya, N.; Zazhigalov, S. Unsteady-state operation of reactors with fixed catalyst beds. Rev. Chem. Eng. 2021, 37, 193-225. [CrossRef]

49. Ventilation Air Methane (VAM) Utilization Technologies. Available online: https:/ /www.epa.gov/sites/production/files/2017-0 1/documents/vam_technologies-1-2017.pdf.pdf (accessed on 27 November 2020).

50. Stolaroff, J.K.; Bhattacharyya, S.; Smith, C.A.; Bourcier, W.L.; Cameron-Smith, P.J.; Aines, R.D. Review of Methane Mitigation Technologies with Application to Rapid Release of Methane from the Arctic. Environ. Sci. Technol. 2012, 46, 6455-6469. [CrossRef]

51. Gosiewski, K.; Pawlaczyk, A. Catalytic or thermal reversed flow combustion of coal mine ventilation air methane: What is better choice and when? Chem. Eng. J. 2014, 238, 78-85. [CrossRef]

52. Mao, M.M.; Shi, J.R.; Liu, Y.Q.; Gao, M.; Chen, Q. Experimental investigation on control of temperature asymmetry and nonuniformity in a pilot scale thermal flow reversal reactor. Appl. Therm. Eng. 2020, 175, 115375. [CrossRef]

53. Zheng, B.; Liu, Y.Q.; Sun, P.; Meng, J.; Liu, R.X. Dehydrogenation characteristics of lean methane in a thermal reverse-flow reactor. Int. J. Hydrog. Energy 2019, 44, 5137-5142. [CrossRef]

54. Lan, B.; Li, Y.R.; Zhao, X.S.; Kang, J.D. Industrial-Scale Experimental Study on the Thermal Oxidation of Ventilation Air Methane and the Heat Recovery in a Multibed Thermal Flow-Reversal Reactor. Energies 2018, 11, 1578. [CrossRef]

55. Gosiewski, K.; Pawlaczyk, A.; Jaschik, M. Thermal combustion of lean methane-Air mixtures: Flow reversal research and demonstration reactor model and its validation. Chem. Eng. J. 2012, 207-208, 76-84. [CrossRef]

56. Setiawan, A.; Kennedy, E.M.; Stockenhuber, M. Development of Combustion Technology for Methane Emitted from Coal-Mine Ventilation Air Systems. Energy Technol. 2017, 5, 521-538. [CrossRef]

57. Yin, J.J.; Su, S.; Yu, X.X.; Bae, J.S.; Jin, Y.G.; Villella, A.; Jara, M.; Ashby, M.; Cunnington, M.; Loney, M. Site Trials and Demonstration of a Novel Pilot Ventilation Air Methane Mitigator. Energy Fuels 2020, 34, 9885-9893. [CrossRef]

58. Gao, P.F.; Gou, X.L. Experimental Research on the Thermal Oxidation of Ventilation Air Methane in a Thermal Reverse Flow Reactor. ACS Omega 2019, 4, 14886-14894. [CrossRef] [PubMed]

59. Marin, P.; Vega, A.; Diez, F.V.; Ordonez, S. Control of regenerative catalytic oxidizers used in coal mine ventilation air methane exploitation. Process. Saf. Environ. Protect. 2020, 134, 333-342. [CrossRef]

60. Salomons, S.; Hayes, R.E.; Poirier, M.; Sapoundjiev, H. Flow reversal reactor for the catalytic combustion of lean methane mixtures. Catal. Today 2003, 83, 59-69. [CrossRef] 
61. Wang, Y.; Man, C.; Che, D. Catalytic Combustion of Ventilation Air Methane in a Reverse-Flow Reactor. Energy Fuels 2010, 24, 4841-4848. [CrossRef]

62. Somers, J.M.; Schultz, H.L. Thermal oxidation of coal mine ventilation air methane. In Proceedings of the 12th U.S./North American Mine Ventilation Symposium, Reno, NV, USA, 9-11 June 2008; pp. 301-305.

63. Shanxi LuAn Group Gaohe Mine VAM Destruction and Utilization Project. Available online: https://cdm.unfccc.int/Projects/ DB/TUEV-RHEIN1352801900.72/view (accessed on 15 June 2021).

64. MEGTEC Systems Inc. Leaflet: Ventilation Air Methane (VAM) Processing. MEGTEC Solutions for VAM Abatement, Energy Recovery E Utilization 2014.

65. U.S. EPA. U.S. Underground Coal Mine Ventilation Air Methane Exhaust Characterization; U.S. EPA: Washington, DC, USA, 2010; pp. $1-16$.

66. Shen, X.; Zhang, B.; Zhang, X.; Wu, S. Explosion behaviors of mixtures of methane and air with saturated water vapor. Fuel 2016, 177, 15-18. [CrossRef]

67. Chen, J.; Wen, G.; Yan, S.; Lan, X.; Xiao, L. Oxidation and Characterization of Low-Concentration Gas in a High-Temperature Reactor. Processes 2020, 8, 481. [CrossRef]

68. Best Practice Guidance for Effective Methane Drainage and Use in Coal Mines. Available online: https://unece.org/DAM/ energy/se/pdfs/cmm/pub/BestPractGuide_MethDrain_es31.pdf (accessed on 30 June 2021).

69. Zheng, B.; Liu, Y.Q.; Liu, R.X.; Meng, J. Catalytic oxidation of coal mine ventilation air methane in a preheat catalytic reaction reactor. Int. J. Hydrog. Energy 2015, 40, 3381-3387. [CrossRef]

70. Zheng, B.; Liu, Y.Q.; Sun, P.; Sun, J.J.; Meng, J. Oxidation of lean methane in a two-chamber preheat catalytic reactor. Int. J. Hydrog. Energy 2017, 42, 18643-18648. [CrossRef]

71. Sekizawa, K.; Widjaja, H.; Maeda, S.; Ozawa, Y.; Eguchi, K. Low temperature oxidation of methane over Pd catalyst supported on metal oxides. Catal. Today 2000, 59, 69-74. [CrossRef]

72. Kucharczyk, B.; Tylus, W.; Kepiński, L. Pd-based monolithic catalysts on metal supports for catalytic combustion of methane. Appl. Catal. B Environ. 2004, 49, 27-37. [CrossRef]

73. Xiao, L.-h.; Sun, K.-p.; Xu, X.-1.; Li, X.-n. Low-temperature catalytic combustion of methane over $\mathrm{Pd} / \mathrm{CeO} 2 \mathrm{prepared} \mathrm{by}$ deposition-precipitation method. Catal. Commun. 2005, 6, 796-801. [CrossRef]

74. Okal, J.; Zawadzki, M.; Baranowska, K. Methane combustion over bimetallic $\mathrm{Ru}-\mathrm{Re} / \gamma-\mathrm{Al}_{2} \mathrm{O}_{3}$ catalysts: Effect of Re and pretreatments. Appl. Catal. B Environ. 2016, 194, 22-31. [CrossRef]

75. Lin, W.; Lin, L.; Zhu, Y.X.; Xie, Y.C.; Scheurell, K.; Kemnitz, E. Novel Pd/SnxZr1-xO 2 catalysts for methane total oxidation at low temperature and their O-18-isotope exchange behavior. Appl. Catal. B-Environ. 2005, 57, 175-181. [CrossRef]

76. Guo, T.Y.; Du, J.P.; Wu, J.T.; Wang, S.; Li, J.P. Structure and kinetic investigations of surface-stepped $\mathrm{CeO}_{2}$-supported Pd catalysts for low-concentration methane oxidation. Chem. Eng. J. 2016, 306, 745-753. [CrossRef]

77. Ercolino, G.; Stelmachowski, P.; Specchia, S. Catalytic Performance of $\mathrm{Pd} / \mathrm{Co}_{3} \mathrm{O}_{4}$ on $\mathrm{SiC}$ and $\mathrm{ZrO} 2$ Open Cell Foams for Process Intensification of Methane Combustion in Lean Conditions. Ind. Eng. Chem. Res. 2017, 56, 6625-6636. [CrossRef]

78. Xiong, J.X.; Wu, K.; Yang, J.; Liu, P.; Song, L.H.; Zhang, J.; Fu, M.L.; Chen, L.M.; Huang, H.M.; Wu, J.L.; et al. The effect of existence states of PdOx supported by $\mathrm{Co}_{3} \mathrm{O}_{4}$ nanoplatelets on catalytic oxidation of methane. Appl. Surf. Sci. 2021, 539, 14. [CrossRef]

79. Lamarino, M.; Chirone, R.; Lisi, L.; Pirone, R.; Salatino, P.; Russo, G. Cu/ $\gamma-\mathrm{Al}_{2} \mathrm{O}_{3}$ catalyst for the combustion of methane in a fluidized bed reactor. Catal. Today 2002, 75, 317-324. [CrossRef]

80. Marín, P.; Ordóñez, S.; Díez, F.V. Performance of silicon-carbide foams as supports for Pd-based methane combustion catalysts. J. Chem. Technol. Biotechnol. 2012, 87,360-367. [CrossRef]

81. Hosseiniamoli, H.; Bryant, G.; Kennedy, E.M.; Mathisen, K.; Nicholson, D.; Sankar, G.; Setiawan, A.; Stockenhuber, M. Understanding Structure-Function Relationships in Zeolite-Supported Pd Catalysts for Oxidation of Ventilation Air Methane. Acs Catal. 2018, 8, 5852-5863. [CrossRef]

82. Guo, T.Y.; Nie, X.R.; Du, J.P.; Li, J.P. Enhanced properties of Pd/CeO2-nanorods modified with alkaline-earth metals for catalytic oxidation of low-concentration methane. Rsc Adv. 2018, 8, 38641-38647. [CrossRef]

83. Huang, Q.F.; Li, W.Z.; Lin, Q.Z.; Zheng, X.S.; Pan, H.B.; Pi, D.; Shao, C.Y.; Hu, C.; Zhang, H.T. Catalytic performance of $\mathrm{Pd}-\mathrm{NiCo}_{2} \mathrm{O}_{4} / \mathrm{SiO}_{2}$ in lean methane combustion at low temperature. J. Energy Inst. 2018, 91, 733-742. [CrossRef]

84. Li, Y.; Armor, J.N. Catalytic combustion of methane over palladium exchanged zeolites. Appl. Catal. B Environ. 1994, 3, 275-282. [CrossRef]

85. Miniajluk, N.; Trawczyński, J.; Zawadzki, M.; Tylus, W. LaMnO $\left(\mathrm{La0} .8 \mathrm{Sr} 0.2 \mathrm{MnO}_{3}\right)$ Perovskites for Lean Methane Combustion: Effect of Synthesis Method. Adv. Mater. Phys. Chem. 2018, 08, 193-215. [CrossRef]

86. Choudhary, V.R.; Patil, V.P.; Jana, P.; Uphade, B.S. Nano-gold supported on $\mathrm{Fe}_{2} \mathrm{O}_{3}$ : A highly active catalyst for low temperature oxidative destruction of methane green house gas from exhaust/waste gases. Appl. Catal. A Gen. 2008, 350, 186-190. [CrossRef]

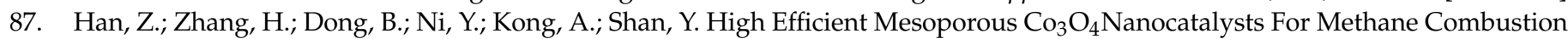
at Low Temperature. Chem. Sel. 2016, 1, 979-983. [CrossRef]

88. Hu, J.; Zhao, W.; Hu, R.; Chang, G.; Li, C.; Wang, L. Catalytic activity of spinel oxides $\mathrm{MgCr}_{2} \mathrm{O}_{4}$ and $\mathrm{CoCr}_{2} \mathrm{O}_{2}$ for methane combustion. Mater. Res. Bull. 2014, 57, 268-273. [CrossRef] 
89. Kruemek, P.; Mattathankul, S.; Triamnak, N.; Chotigkrai, N. Iop. A facile synthesis of CuCe and CuCeFe mixed-oxide catalysts by solution combustion method for catalytic methane combustion. In Proceedings of the 26th Regional Symposium on Chemical Engineering (RSCE), Kuala Lumpur, Malaysia, 30-31 October 2019.

90. Hosseiniamoli, H.; Setiawan, A.; Adesina, A.A.; Kennedy, E.M.; Stockenhuber, M. The stability of Pd/TS-1 and Pd/silicalite-1 for catalytic oxidation of methane-Understanding the role of titanium. Catal. Sci. Technol. 2020, 10, 1193-1204. [CrossRef]

91. Zedan, A.F.; AlJaber, A.S. Combustion Synthesis of Non-Precious $\mathrm{CuO}-\mathrm{CeO}_{2}$ Nanocrystalline Catalysts with Enhanced Catalytic Activity for Methane Oxidation. Materials 2019, 12, 878. [CrossRef]

92. Kucharczyk, B. Activity of monolithic $\mathrm{Pd} / \mathrm{Al}_{2} \mathrm{O}_{3}$ catalysts in the combustion of mine ventilation air methane. Pjct 2011, 13, 57-62. [CrossRef]

93. Narui, K.; Yata, H.; Furuta, K.; Nishida, A.; Kohtoku, Y.; Matsuzaki, T. Effects of addition of Pt to PdO/ $\mathrm{Al}_{2} \mathrm{O}_{3}$ catalyst on catalytic activity for methane combustion and TEM observations of supported particles. Appl. Catal. A Gen. 1999, 179, 165-173. [CrossRef]

94. Ishihara, T.; Shigematsu, H.; Abe, Y.; Takita, Y. Effects of Additives on the Activity of Palladium Catalysts for Methane Combustion. Chem. Lett. 1993, 22, 407-410. [CrossRef]

95. Xiong, J.; Mo, S.; Song, L.; Fu, M.; Chen, P.; Wu, J.; Chen, L.; Ye, D. Outstanding stability and highly efficient methane oxidation performance of palladium-embedded ultrathin mesoporous $\mathrm{Co}_{2} \mathrm{MnO}_{4}$ spinel catalyst. Appl. Catal. A Gen. 2020, 598, 117571 . [CrossRef]

96. Ahmad, Y.H.; Mohamed, A.T.; Al-Qaradawi, S.Y. Exploring halloysite nanotubes as catalyst support for methane combustion: Influence of support pretreatment. Appl. Clay Sci. 2021, 201, 9. [CrossRef]

97. Geng, H.J.; Yang, Z.Q.; Zhang, L.; Ran, J.Y.; Chen, Y.R. Experimental and kinetic study of methane combustion with water over copper catalyst at low-temperature. Energy Convers. Manag. 2015, 103, 244-250. [CrossRef]

98. Gao, X.J.; Jin, Z.H.; Hu, R.S.; Hu, J.N.; Bai, Y.Q.; Wang, P.; Zhang, J.; Zhao, C.X. Double perovskite anti-supported rare earth oxide catalyst $\mathrm{CeO}_{2} / \mathrm{La}_{2} \mathrm{CoFeO}_{6}$ for efficient ventilation air methane combustion. J. Rare Earths 2021, 39, 398-408. [CrossRef]

99. Chen, J.; Arandiyan, H.; Gao, X.; Li, J. Recent Advances in Catalysts for Methane Combustion. Catal. Surv. Asia 2015, 19, 140-171. [CrossRef]

100. Specchia, S.; Finocchio, E.; Busca, G.; Palmisano, P.; Specchia, V. Surface chemistry and reactivity of ceria-zirconia-supported palladium oxide catalysts for natural gas combustion. J. Catal. 2009, 263, 134-145. [CrossRef]

101. Zanoletti, M.; Godard, F.; Perrier, M. Effect of support on the apparent activity of palladium oxide in catalytic methane combustion. Can. J. Chem. Eng. 2020, 98, 2205-2213. [CrossRef]

102. Wang, S.; Gao, D.N.; Wang, S.D. Steady and Transient Characteristics of Catalytic Flow Reverse Reactor Integrated with Central Heat Exchanger. Ind. Eng. Chem. Res. 2014, 53, 12644-12654. [CrossRef]

103. Coney, C.; Stere, C.; Millington, P.; Raj, A.; Wilkinson, S.; Caracotsios, M.; McCullough, G.; Hardacre, C.; Morgan, K.; Thompsett, D.; et al. Spatially-resolved investigation of the water inhibition of methane oxidation over palladium. Catal. Sci. Technol. 2020, 10, 1858-1874. [CrossRef]

104. Stasinska, B.; Machocki, A.; Antoniak, K.; Rotko, M.; Figueiredo, J.L.; Gonçalves, F. Importance of palladium dispersion in $\mathrm{Pd} / \mathrm{Al}_{2} \mathrm{O}_{3}$ catalysts for complete oxidation of humid low-methane-air mixtures. Catal. Today 2008, 137, 329-334. [CrossRef]

105. Ordonez, S.; Hurtado, P.; Sastre, H.; Diez, F.V. Methane catalytic combustion over Pd/Al2O3 in presence of sulphur dioxide: Development of a deactivation model. Appl. Catal. A-Gen. 2004, 259, 41-48. [CrossRef]

106. Nawrat, S.; Gatnar, K. Ocena stanu i możliwości utylizacji metanu z powietrza wentylacyjnego podziemnych kopalń węgla kamiennego. Polityka Energetyczna 2008, 11, 69-84.

107. Su, S.; Ren, T.; Balusu, R.; Beath, A.; Guo, H.; Mallett, C. Development of Two Case Studies on Mine Methane Capture and Utilisation in China. CSIRO - Report P2006/17; CSIRO: Kenmore, Australia, 2006.

108. Carothers, P.; Deo, M. Technical and Economic Assessment: Mitigation of Methane Emissions from Coal Mine Ventilation Air. Coalbed Methane Outreach Program; U.S. EPA: Washington, DC, USA, 2000; p. 96.

109. Tsyrulnikov, P.G.; Sal'nikov, V.S.; Drozdov, V.A.; Noskov, A.S.; Chumakova, N.A.; Ermolaev, V.K.; Malakhova, I.V. Deep Oxidation of Methane on Alumina-Manganese and Pt-Containing Catalysts. J. Catal. 2001, 198, 164-171. [CrossRef]

110. Gogin, L.L.; Matros, L.L.; Ivanov, A.G. Ekologiia i Kataliz [Ecology and Catalysis]; (in Russian). Izd. Nauka: Novosibirsk, Russia, 1990; p. 107.

111. Stasińska, B. Ograniczenie emisji metanu z kopalń węglowych poprzez katalityczne oczyszczanie powietrza wentylacyjnego. Polityka Energetyczna 2009, 12, 123-132.

112. Mallett, C.; Su, S. Progress in Developing Ventilation Air Methane Mitigation and Utilization Technologies. In Proceedings of the Third International Methane and Nitrous Oxide Mitigation Conference, Beijing, China, 17-21 November $2003 ; 2003$.

113. Sapoundjiev, H.; Trottier, R.; Aube, F. Heat recovery from lean industrial emissions. Enviromental and economic benefits of CFRR technology. Greenh. Gas. Control. Technol. 1999, 805-810.

114. Marin, P.; Hevia, M.A.G.; Ordonez, S.; Diez, F.V. Combustion of methane lean mixtures in reverse flow reactors: Comparison between packed and structured catalyst beds. Catal. Today 2005, 105, 701-708. [CrossRef]

115. Urbani, C.; Marin, P.; Diez, F.V.; Ordonez, S. Catalytic combustion of sulphur-containing methane lean emissions in a reverse-flow reactor with integrated adsorption. Chem. Eng. J. 2016, 285, 39-48. [CrossRef]

116. Fernandez, J.; Marin, P.; Diez, F.V.; Ordonez, S. Coal mine ventilation air methane combustion in a catalytic reverse flow reactor: Influence of emission humidity. Fuel Process. Technol. 2015, 133, 202-209. [CrossRef] 
117. Universitaet Stuttgart; European Union. European Union Project (Contract, No. ICA2-CT-2000-10035): Recovery of methane from vent gases of coal mines and its efficient utilization as a high temperature heat source - Final Report; Universitaet Stuttgart: Stuttgart, Germany, 2003.

118. Gosiewski, K. Efficiency of heat recovery versus maximum catalyst temperature in the reverse-flow combustion of methane. Chem. Eng. J. 2005, 107, 19-25. [CrossRef]

119. Sapoundjiev, H.; Aubé, F.; Trottier, R. Report: Elimination of dilute methane emissions from underground mine and oil and natural gas production sectors. CANMET, Natural Resources Canada; Canadian Environment Industry Association: Ottawa, ON, Canada, 1999.

120. Slepterev, A.A.; Salnikov, V.S.; Tsyrulnikov, P.G.; Noskov, A.S.; Tomilov, V.N.; Chumakova, N.A.; Zagoruiko, A.N. Homogeneous high-temperature oxidation of methane. React. Kinet. Catal. Lett. 2007, 91, 273-282. [CrossRef]

121. Gosiewski, K.; Pawlaczyk, A.; Warmuzinski, K.; Jaschik, M. A study on thermal combustion of lean methane-Air mixtures: Simplified reaction mechanism and kinetic equations. Chem. Eng. J. 2009, 154, 9-16. [CrossRef]

122. Tsyrulnikov, P.G.; Tsybulya, S.V.; Kryukova, G.N.; Boronin, A.I.; Koscheev, S.V.; Starostina, T.G.; Bubnov, A.V.; Kudrya, E.N. Phase transformations in the thermoactivated $\mathrm{MnO}_{x}-\mathrm{Al}_{2} \mathrm{O}_{3}$ catalytic system. J. Mol. Catal. A Chem. 2002, 170, 213-220. [CrossRef]

123. Gosiewski, K.; Machej, T.; Janas, J.; Sadowska, H.; Warmuziński, K. Kinetyka katalitycznego spalania metanu w małym stężeniu. Inżynieria Chem. I Proces. 2001, 22, 599-612.

124. Gosiewski, K.; Warmuziński, K.; Tańczyk, M.; Moszczyński, M.; Jaschik, J.; Zielińska, I.; Giełzak, K. Projekt badawczy KBN nr 3 TO9C 042 18: Katalityczne usuwanie metanu z górniczych gazów wentylacyjnych w reaktorach niestacjonarnych ze wstępnym wzbogacaniem mieszaniny gazowej metoda adsorpcji zmiennociśnieniowej; Institute of Chemical Engineering PAS: Gliwice, Poland, 2001-2003.

125. Bos, A.N.R.; Lange, J.P.; Kabra, G. A novel reverse flow reactor with integrated separation. Chem. Eng. Sci. 2007, 62, 5661-5662. [CrossRef]

126. Fernandez, J.; Marin, P.; Diez, F.V.; Ordonez, S. Combustion of coal mine ventilation air methane in a regenerative combustor with integrated adsorption: Reactor design and optimization. Appl. Therm. Eng. 2016, 102, 167-175. [CrossRef]

127. Kucharczyk, B.; Stasińska, B.; Nawrat, S. Studies on work of a prototype installation with two types of catalytic bed in the reactor for oxidation of methane from mine ventilation air. Fuel Process. Technol. 2017, 166, 8-16. [CrossRef]

128. Salamon, E.; Cornejo, I.; Mmbaga, J.P.; Kolodziej, A.; Lojewska, J.; Hayes, R.E. Investigations of a three channel autogenous reactor for lean methane combustion. Chem. Eng. Process.-Process. Intensif. 2020, 153, 9. [CrossRef]

129. Yonggang, J.; Shi, S. Proof-of-Concept Photocatalytic Destruction of Methane for Coal Mining Fugitive Emissions Abatement. Available online: https:/ / www.acarp.com.au/abstracts.aspx?repId=C24061 (accessed on 20 June 2021). 